\title{
Modelling seabed sediment physical properties and organic matter content in the Firth of Clyde
}

\author{
Matthew C. Pace ${ }^{1}$, David M. Bailey ${ }^{1}$, David W. Donnan ${ }^{2}$, Bhavani E. Narayanaswamy ${ }^{3}$, Hazel J. Smith ${ }^{4}$,
} Douglas C. Speirs ${ }^{4}$, William R. Turrell ${ }^{5}$, Michael R. Heath ${ }^{4}$

5 Institute of Biodiversity, Animal Health and Comparative Medicine, University of Glasgow, Glasgow, G12 8QQ, UK

${ }^{2}$ NatureScot, Perth, PH1 3EW, UK

${ }^{3}$ Scottish Association for Marine Science, Oban, PA37 1QA, UK

${ }^{4}$ Department of Mathematics and Statistics, University of Strathclyde, Glasgow, G1 1XH, UK

${ }^{5}$ Marine Scotland Science, Aberdeen, AB11 9DB, UK

10 Correspondence to: Matthew C. Pace (m.pace.1@research.gla.ac.uk)

\begin{abstract}
High quality quantitative maps of seabed sedimentary physical and geochemical properties have numerous research and conservation applications, including habitat and ecosystem modelling, marine spatial planning and ecosystem service mapping. However, such maps are lacking for many ecologically and economically important marine areas. Using legacy data supplemented by measurements from recent benthic surveys, modelled hydrodynamic variables and high resolution

15 bathymetry, quantitative maps for the top $10 \mathrm{~cm}$ of seabed sediment were generated via a combination of statistical and machine-learning techniques for the Firth of Clyde, a semi-enclosed coastal sea on the west coast of Scotland. The maps include sediment fractions of mud, sand and gravel, whole-sediment median grain size, sediment permeability and porosity, rates of natural seabed abrasion, and sediment particulate organic carbon and nitrogen content. Properties were mapped over an unstructured grid, so that very high resolutions were achieved close to the coastlines, where sediments may be expected to

20 be spatially heterogeneous.

Overall, the maps reveal extensive areas of very low sediment permeability coupled with low rates of natural seabed disturbance. Moreover, muddy sediments in the inner Firth of Clyde, Inchmarnock Water and the sea lochs are enriched in organic carbon and nitrogen relative to the sediments of the outer Firth of Clyde. As a demonstration of the value of these maps, the standing stock of organic carbon and nitrogen in the surficial sediments of the Clyde was calculated. The Clyde stores 3.42 and 0.33 million tonnes of organic carbon and nitrogen in the top $10 \mathrm{~cm}$ of seabed sediment, respectively, substantially contributing to Scotland's coastal and shelf blue carbon stocks. Data products are available from: https://doi.org/10.15129/2003faa2-ee93-4c11-bb16-48485f5f136d.
\end{abstract}

\section{Introduction}

Seabed surficial sediment properties are a defining feature of shelf-sea ecosystems, determining organic matter storage,

30 nutrient recycling and contaminant degradation, turbidity, habitat availability for, and productivity of benthos and fish (Ehrenhauss et al., 2004; Janssen et al., 2005; Kamann et al., 2007; Neumann et al., 2017b; Serpetti et al., 2016). Maps of 
https://doi.org/10.5194/essd-2021-23

Preprint. Discussion started: 17 May 2021

(c) Author(s) 2021. CC BY 4.0 License.

sediment properties are therefore important for marine planning and conservation (e.g. Schiele et al., 2015), and assessments of marine service provision (Cowling et al., 2008; Townsend et al., 2014), especially in coastal waters where anthropogenic disturbance is often greatest (Eigaard et al., 2017) and sediments can be extremely heterogeneous (Serpetti et al., 2011).

35 However, maps of adequate resolution are lacking for many regions.

For many decades the standard procedure for characterising seabed sediment samples involved sieving through standard meshes to separate fractions designated mud (sometimes divided into silt and clay), sand and gravel. The proportions by weight of these fractions were then used to classify the sediment usually according to either the Wentworth or Folk scheme (Folk, 1954; Wentworth, 1922). In reality the grain size boundaries between these three fractions are arbitrary, the classification

40 schemes themselves are a compromise between simplicity and detail, and they were originally designed for specific purposes - for example the Folk scheme was designed to resolve the importance of transport on sediment grain distributions (Valentine, 2019).

Recent seabed sediment samples are often analysed by laser diffraction instruments which provide a finely resolved size distribution of grain sizes. These instruments offer measurements of sediment properties on a continuous scale rather than by class, e.g. median grain size, skewness, kurtosis. These properties can be related to other more-difficult-to-measure features such as porosity, permeability and organic matter content. However, it is often the case that laser size distributions are aggregated to the traditional sieve-based mud, sand and gravel size classes so that sediments can be classified according to the traditional Folk or Wentworth schemes, or similar (e.g. Lepland et al., 2014), and the continuous variable data are not reported. Note however that there may not be a simple 1:1 relationship between laser size classes and sieve-based classes (Fisher et al.,

50 2017; Wilson et al., 2018).

Most seabed sediment maps display classification data, e.g. https://www.bgs.ac.uk/data/services/offprodwms.html; http://www.mareano.no/kart/mareano_en.html?language=en. The reason is that for the main part they rely on sample data accumulated over many decades, most of which is class-based. However, classification maps have a number of limitations. In particular, they are not easily scalable to finer resolution. For example the EMODnet seabed habitat classification map is gridded at a resolution of approximately $100 \mathrm{~m}$ (https://www.emodnet-seabedhabitats.eu/), but the sediment class descriptors are so broad that areas of shelf and coastal seabed are portrayed as homogeneous at scales of 10's of km. In reality, there may be important heterogeneity in whole-sediment grain size compositions which cannot be resolved by the classification scheme. Misiuk et al. (2019) compared and contrasted categorical and continuous variable approaches to mapping seabed sediments and for one particular case study found that both had a similar performance. However, while this may be true generally, it remains the case that it is extremely difficult to meaningfully recover whole-sediment continuous properties such as median grain size, or mud content from class-based data. These properties are the key to imputing other hard-to-measure variables such as carbon content or permeability, based on statistical relationships developed from more limited sampling. Several authors have attempted to extract estimates of such variables from categorical data (Burrows et al., 2014; Diesing et al., 2017; Smeaton et al., 2020), but this approach may lead to over- or under-predictions especially for properties like permeability which vary by several orders of magnitude within a single grain size class (Serpetti et al., 2016). 
https://doi.org/10.5194/essd-2021-23

Preprint. Discussion started: 17 May 2021

(c) Author(s) 2021. CC BY 4.0 License.

Sediment carbon inventories are a case in point with regard to class-based data. Smeaton et al. (2020) estimated the marine sedimentary carbon stock in Scottish shelf seas from the British Geological Survey 1:25000 seabed sediment classification, but resorted to assigning a mean carbon content to each class based on samples collected only in the North Sea (Diesing et al., 2017), and integrating the areas of each sediment class. In contrast, using methods similar to Stephens and Diesing (2015),

70 Wilson et al. (2018) used Random Forest algorithms to generate synthetic maps of sediment carbon content across the whole NW European shelf by blending interpolated and predicted maps (0.125-degree resolution - approximately $10 \mathrm{~km})$. Interpolation was confined to the alphahull of raw samples assembled from international databases within which sample density exceeded a given threshold. Outside this hull the distributions were predicted by a Random Forest with inputs of bathymetric and hydrodynamic data.

75 Wilson et al. (2018) also used the Random Forest approach to map mud, sand and gravel compositions, porosity, permeability, and the probability of encountering exposed bedrock. Mitchell et al. (2019) used a similar approach to modelling mud, sand and gravel composition at higher spatial resolution (approximately $0.2 \mathrm{~km}$ ). Data products from studies such as these have proved to be extremely valuable and have been used in a range of different applications including biodiversity - ecosystem functioning relationships (Maureaud et al., 2019), benthic community sensitivity to trawling disturbance (Rijnsdorp et al.,

80 2018), and the economic cost of disrupting sedimentary carbon storage (Luisetti et al., 2019).

Here, the approach taken by Wilson et al. (2018) was followed and applied at very high spatial resolution (down to $50 \mathrm{~m}$ ) in a semi-enclosed coastal sea (Firth of Clyde, SW Scotland) where there are strong gradients of bathymetry, tidally dominated hydrodynamics, and sediment properties. The Firth of Clyde and associated sea-lochs feature several deep post-glacial basins lined with very fine, organic-rich mud which has been heavily impacted by trawling (McIntyre et al., 2012). To-date, sediments

85 in the Clyde have only been mapped at a coarse-resolution or as part of larger continental shelf mapping exercises (e.g. Diesing et al., 2017; Mitchell et al., 2019; Wilson et al., 2018). In the following sections, the compilation of legacy data and the collection of additional field samples and their laboratory analysis is first reported. Subsequently, statistical modelling methods used to generate the maps from the source data and the subsequent validation of these data products is described. Finally, an application of these data products to calculate the standing stock of organic carbon and nitrogen in the surficial sediment of

90 the Firth of Clyde is presented and the implications for future research discussed.

\section{Methods}

\subsection{Study area}

The scope of this study is the generation of high resolution full-coverage maps for sediment fractions of mud, sand and gravel, whole-sediment median grain size, sediment permeability and porosity, rates of natural seabed abrasion, and sediment particulate organic carbon and nitrogen content in the Firth of Clyde. The Firth of Clyde is situated on the west coast of Scotland and covers an area of approximately $3600 \mathrm{~km}^{2}$ (Fig. 1). 

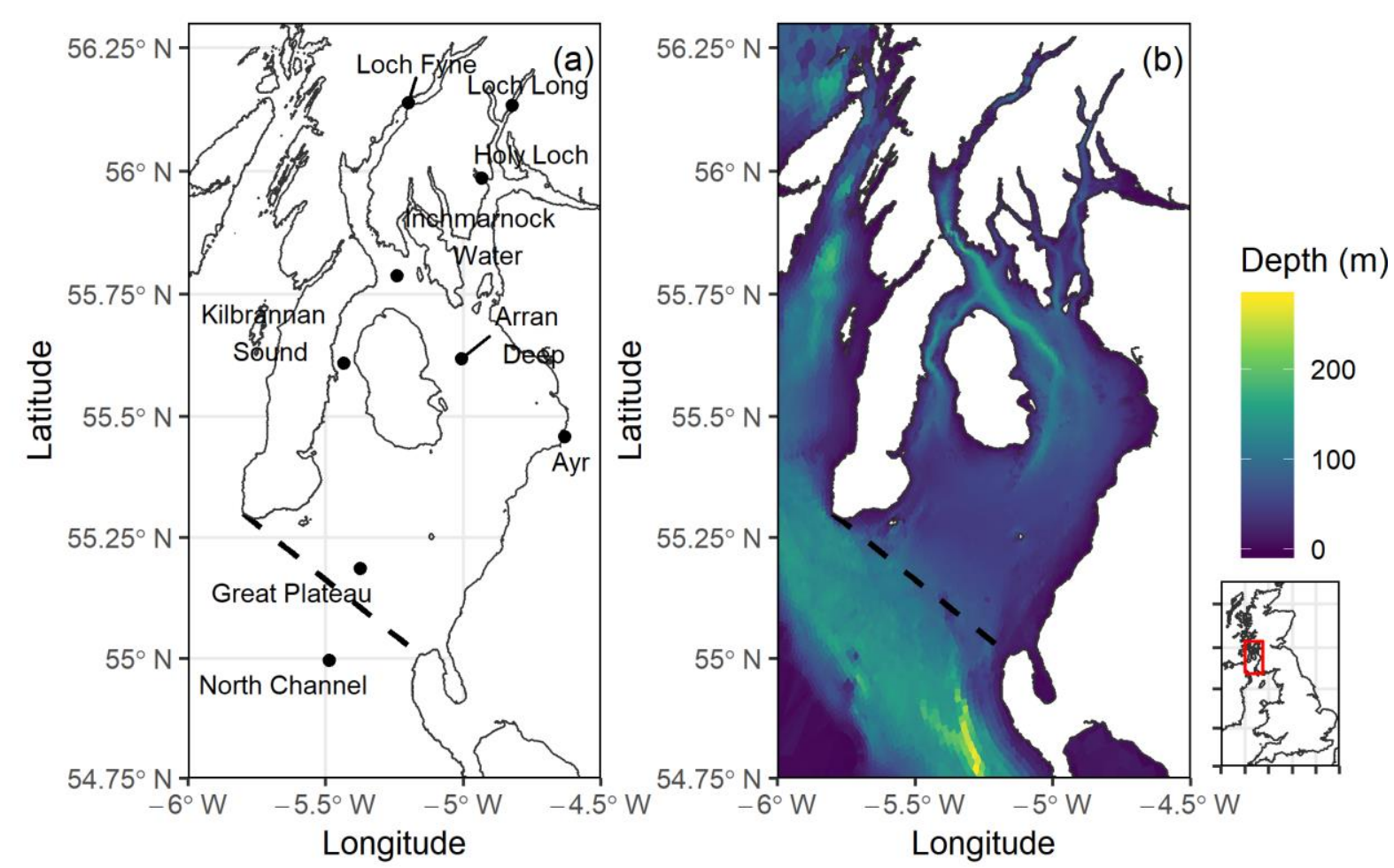

Figure 1 Maps of the Firth of Clyde showing (a) locations referred to in text and, (b) bathymetry mapped over an unstructured grid. Seabed depth is shown in metres and the dashed line shoes the outer geographical limits of the Firth of Clyde. The location of the Firth of Clyde on the west coast of Scotland is shown inset. Bathymetry data source: Sabatino et al. (2016).

\subsection{Data centres and legacy data}

The compilation and initial processing of data from the Firth of Clyde is outlined in the following sections. Where measurements of key variables for the Firth of Clyde were lacking or sparse, measurements were supplemented with data from surrounding coastal seas. The sources of data used in the analyses described below are listed in Table 1 .

Table 1 Sources of seabed data from data centres and published literature, and the number of records used from each source. Sources include British Geographical Survey (BGS), Marine Scotland Science (MSS), Scottish Environmental Protection Agency (SEPA) and the Centre for Environment, Fisheries and Aquaculture Science (CEFAS).

\begin{tabular}{llllllll}
\hline Property & Symbol & Units & $\begin{array}{l}\text { Data } \\
\text { source }\end{array}$ & $\begin{array}{l}\text { Number } \\
\text { of } \\
\text { records }\end{array}$ & $\begin{array}{l}\text { Temporal } \\
\text { coverage }\end{array}$ & Region & Definition \\
\hline $\begin{array}{l}\text { Presence of } \\
\text { hard } \\
\text { substrate }\end{array}$ & - & - & BGS & - & - & $\begin{array}{l}\text { Firth of } \\
\text { Clyde }\end{array}$ & $\begin{array}{l}\text { Presence of rocky } \\
\text { outcrops and hard } \\
\text { substrate within } 0.5 \mathrm{~m} \\
\text { of the seabed }\end{array}$ \\
& - & $\%$ & BGS & 930 & $\begin{array}{l}1969- \\
\text { Percentage by volume }\end{array}$ \\
& & & & $\begin{array}{l}\text { Firth of } \\
\text { Clyde }\end{array}$ & $\begin{array}{l}\text { Per mud, sand and } \\
\text { of }\end{array}$
\end{tabular}




\begin{tabular}{|c|c|c|c|c|c|c|c|}
\hline $\begin{array}{l}\text { Sediment } \\
\text { grain size }\end{array}$ & & & MSS & 447 & $\begin{array}{l}1997- \\
2011\end{array}$ & $\begin{array}{l}\text { Firth of } \\
\text { Clyde }\end{array}$ & $\begin{array}{l}\text { gravel fractions of } \\
\text { dried sediment }\end{array}$ \\
\hline fractions & & & SEPA & 77 & $\begin{array}{l}2005- \\
2016\end{array}$ & $\begin{array}{l}\text { Firth of } \\
\text { Clyde }\end{array}$ & \\
\hline \multirow[t]{2}{*}{$\begin{array}{l}\text { Median grain } \\
\text { size }\end{array}$} & $D_{50}$ & $\mathrm{~mm}$ & CEFAS & 1873 & $\begin{array}{l}1998- \\
2010\end{array}$ & $\begin{array}{l}\text { Celtic } \\
\text { Sea, } \\
\text { English } \\
\text { Channel, } \\
\text { North Sea }\end{array}$ & $\begin{array}{l}\text { Grain diameter that is } \\
\text { larger than } 50 \% \text { of } \\
\text { other particles }\end{array}$ \\
\hline & & & MSS & 1214 & $\begin{array}{l}2003- \\
2004\end{array}$ & North Sea & \\
\hline Permeability & $\kappa$ & $\mathrm{m}^{2}$ & $\begin{array}{l}\text { Serpetti et } \\
\text { al. (2016) }\end{array}$ & 163 & $\begin{array}{l}2008- \\
2009\end{array}$ & North Sea & $\begin{array}{l}\text { Connectedness of } \\
\text { fluid-filled pore-space } \\
\text { within the sediment }\end{array}$ \\
\hline \multirow[t]{3}{*}{ Porosity } & $\phi$ & $\%$ & $\begin{array}{l}\text { Lohse et } \\
\text { al. (1993) }\end{array}$ & 7 & $\begin{array}{l}1991- \\
1992\end{array}$ & North Sea & $\begin{array}{l}\text { Proportion of pore- } \\
\text { space volume within }\end{array}$ \\
\hline & & & $\begin{array}{l}\text { Ruardij } \\
\text { and van } \\
\text { Raaphorst } \\
(1995)\end{array}$ & 49 & - & North Sea & the sediment \\
\hline & & & $\begin{array}{l}\text { Serpetti et } \\
\text { al. (2016) }\end{array}$ & 166 & $\begin{array}{l}2008- \\
2009\end{array}$ & North Sea & \\
\hline $\begin{array}{l}\text { Particulate } \\
\text { organic } \\
\text { carbon }\end{array}$ & POC & $\begin{array}{l}\%, \mathrm{mg} \mathrm{g}^{-1} \\
\mathrm{dw}\end{array}$ & SEPA & 168 & $\begin{array}{l}2005- \\
2006\end{array}$ & $\begin{array}{l}\text { Firth of } \\
\text { Clyde }\end{array}$ & $\begin{array}{l}\text { Particulate organic } \\
\text { carbon in milligrams } \\
\text { per gram dried } \\
\text { sediment }\end{array}$ \\
\hline $\begin{array}{l}\text { Particulate } \\
\text { organic } \\
\text { nitrogen }\end{array}$ & PON & $\begin{array}{l}\%, \mathrm{mg} \mathrm{g}^{-1} \\
\mathrm{dw}\end{array}$ & SEPA & 118 & $\begin{array}{l}2005- \\
2006\end{array}$ & $\begin{array}{l}\text { Firth of } \\
\text { Clyde }\end{array}$ & $\begin{array}{l}\text { Particulate organic } \\
\text { nitrogen in milligrams } \\
\text { per gram dried } \\
\text { sediment }\end{array}$ \\
\hline
\end{tabular}

\subsubsection{Rock distribution}

110 Although rock outcrops and hard substrata cover a relatively small proportion of the total seabed area in the Firth of Clyde, they play a functionally distinct role as benthic habitats and in the cycling of nutrients within marine ecosystems. Hence, for a complete characterisation of seabed properties, the distinction between areas of sediment and hard substrate is important.

The most extensive available dataset on the distribution of bare-rock and hard substrate features in Scottish coastal waters was compiled by the British Geographical Survey (BGS) from the interpretation of archived acoustic data and seabed samples

115 (http://www.bgs.ac.uk/discoverymetadata/13605550.html). These data were obtained as polygons representing areas of hard substrate, defined by BGS as rock and sediments with a grain size of larger than $64 \mathrm{~mm}$ within $0.5 \mathrm{~m}$ of the seabed (Gafeira et al., 2010). Additional point observations of seabed substrate in the Clyde estuary were digitised from the Admiralty chart no. 2007 covering the River Clyde. 
https://doi.org/10.5194/essd-2021-23

Preprint. Discussion started: 17 May 2021

(c) Author(s) 2021. CC BY 4.0 License.

\subsubsection{Sediment grain size fractions}

120 Data on the percentages mud, sand and gravel in Firth of Clyde sediments from BGS and Marine Scotland were inherited from Wilson et al. (2018), and additional legacy measurements were requested from the Scottish Environmental Protection Agency (SEPA). Marine Scotland data comprised percentages of mud and sand, excluding the gravel fraction. BGS data were derived from samples collected during cruises carried out in the late 1960s and 1970s with detailed information on sample collection and processing in Chesher et al. (1972) and Deegan et al. (1973). SEPA measurements were made from grab samples collected annually from a network of 18 stations to fulfil the Clean Safe Seas Environmental Monitoring Programme (CSEMP) reporting obligations as well as additional surveys. Sampled locations were well-distributed across the Firth of Clyde and in the associated sea lochs with a high density of points in the outer Firth (Fig. 2).

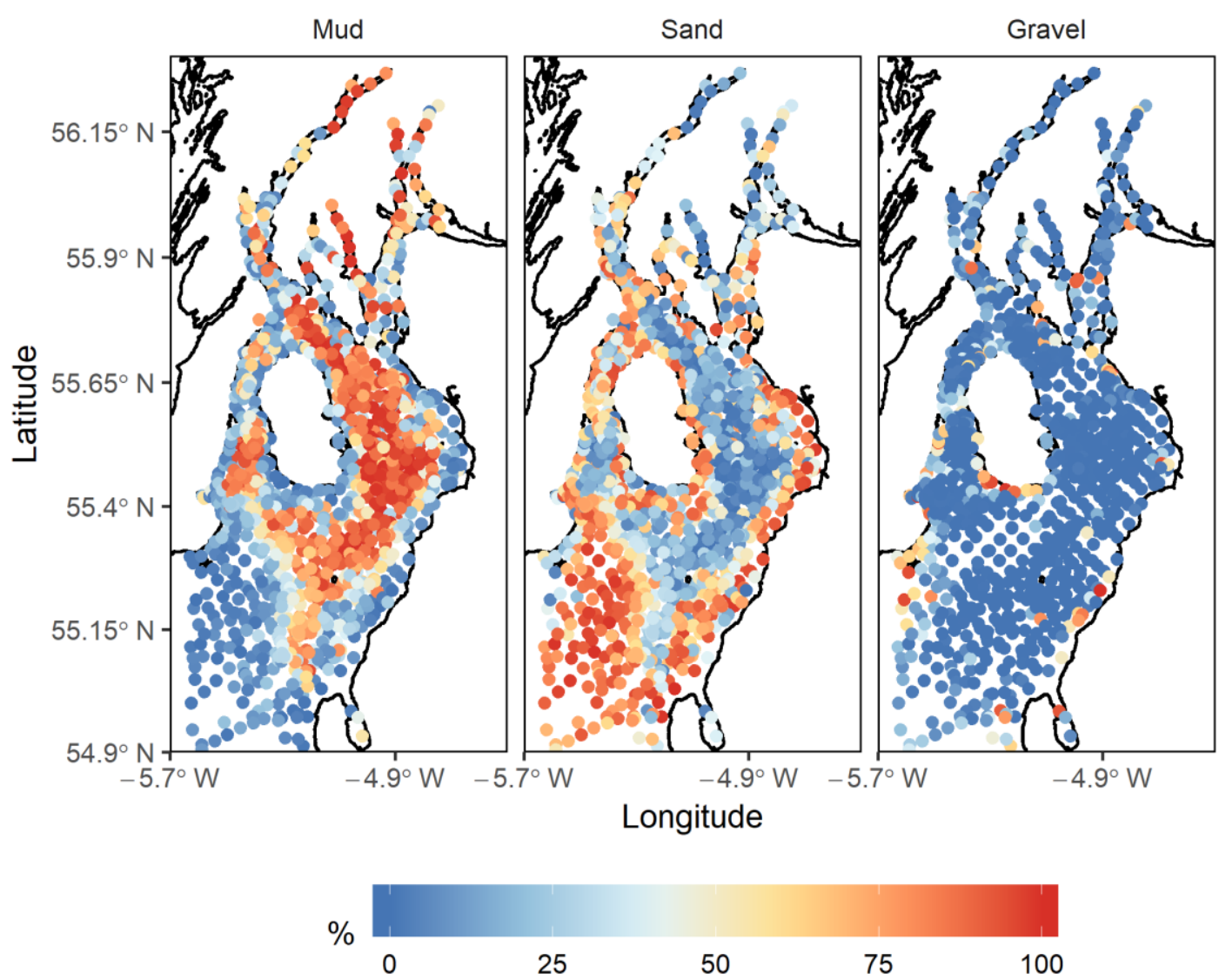

Figure 2 Locations sampled by BGS, MSS and SEPA for the measurement of percentage mud, sand and gravel in seabed sediments in the Firth of Clyde.

The data were filtered to retain only grab samples and maintain a consistent sampling method. Analysis techniques differed between sources. Sediment fractions reported by BGS were measured from sieved samples, whereas Marine Scotland and SEPA data were obtained via laser diffraction analysis. Inconsistency between measurements derived from laser and sieve 
https://doi.org/10.5194/essd-2021-23

Preprint. Discussion started: 17 May 2021

(c) Author(s) 2021. CC BY 4.0 License.

(c) (i)

methods have long been reported in the literature. A correction formula by Wilson et al. (2018) was used to correct sieve diffraction-derived mud and sand fraction measurements in samples containing less than $60 \%$ mud to laser-measured equivalents. The numbers of records used in the analysis from each data source are shown in Table 1.

\subsubsection{Median grain size}

Whole-sediment median grain size data for the Firth of Clyde are sparse. Marine Scotland sediment data for the Firth of Clyde include measurements of median grain size for only the combined mud and sand fractions and these were therefore omitted

140 from the analysis. However, whole-sediment median grain size is related to the proportions of mud, sand and gravel fractions (Wilson et al., 2018). Hence, data comprising these variables and collected by the Centre for Environment, Fisheries and Aquaculture Science (CEFAS) from the Celtic Sea, English Channel and North Sea, and data collected by Marine Scotland from the North Sea were used (Fig. 3).

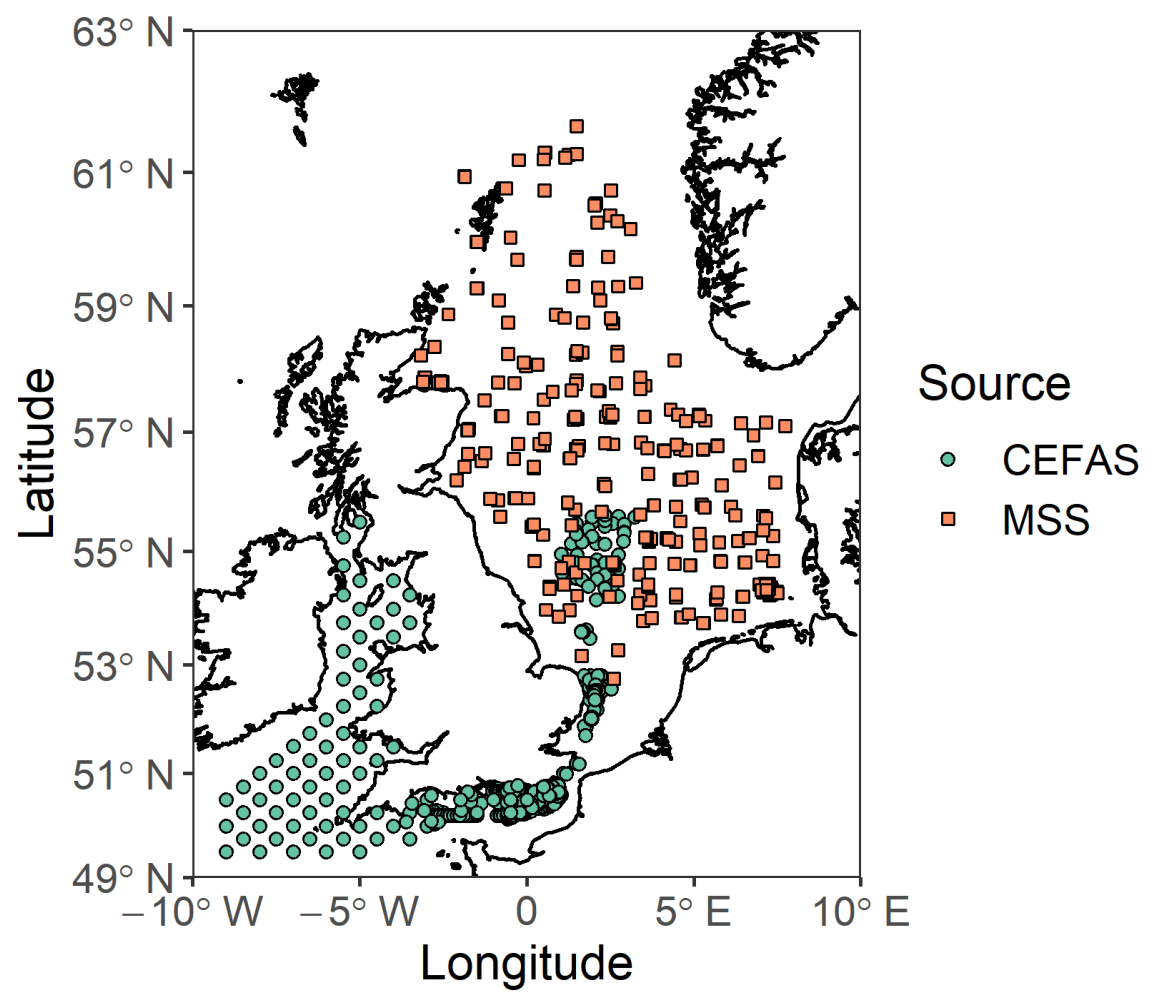

145 Figure 3 Sampling locations for sediment data obtained from CEFAS and MSS for the statistical modelling of relationships between median grain size and fractions of mud, sand and gravel. 
https://doi.org/10.5194/essd-2021-23

Preprint. Discussion started: 17 May 2021

(c) Author(s) 2021. CC BY 4.0 License.

(c) (i)

\subsubsection{Permeability and porosity}

Measurements of seabed sediment permeability and porosity in the Firth of Clyde are lacking. Given the difficulty of carrying out permeability measurements on fresh samples of undisturbed seabed sediment (Wilson et al., 2008), there are few published datasets on the permeability of marine sediments available globally. Extensive work has been carried out to empirically relate permeability to measurements of grain size distribution for a range of sediment types (Qi et al., 2015; see review and metaanalysis by Shepherd, 1989). Recent parameterisations of empirical expressions predicting marine sediment permeability from grain size variables have been carried out by Wilson et al. (2018) and Neumann et al. (2017a). However, there remains considerable uncertainty regarding the suitability of these expressions for predicting the permeability of muddy seabed given the lack of data for fine-grained sediments. The best available dataset on seabed sediment permeability was collected by Serpetti et al. (2016) for seven stations off Stonehaven in the North Sea between 2008 and 2009. This spans 163 measurements of permeability, median grain size and percentages of mud, sand and gravel in the top $10 \mathrm{~cm}$ of seabed sediment from undisturbed cores collected from a range of sediment types.

Sediment porosity is inversely related to grain size (Moore and Keller, 1984). Sediment porosity and median grain size data for the North Sea representative of the top $10 \mathrm{~cm}$ of sediment and published by Lohse et al (1993), Ruardij and van Raaphorst (1995) and Serpetti et al (2016) were used.

\subsubsection{Fishing abrasion pressure}

In recent years, the use of seabed swept-area ratio (SAR) as a quantitative metric of seabed fishing pressure has gained traction in the published literature (Bolam et al., 2017; e.g. Hiddink et al., 2016; Rijnsdorp et al., 2016). SAR is the ratio between the total area swept by the gears of a fishing fleet and the area of grid cell that the values were aggregated over (Eigaard et al., 2016, 2017). To briefly summarise the process of computing SAR, Vessel Monitoring System (VMS) positions are merged with logbook data to obtain locations of fishing operations. These are then combined with footprint estimates for given gear arrangements to obtain the area swept by the gear and then aggregated over a regular grid.

Data for the seabed-surface swept-area ratio calculated over a regular grid at a resolution of $0.05^{\circ} \mathrm{x} 0.05^{\circ}$ was obtained from the Joint Nature Conservation Committee (JNCC) for the period 2009 - 2016. These data cover UK vessels only (D. Edwards, pers. comm.), and it is therefore assumed that the number of non-UK vessels fishing in the Clyde is negligible. Given that these data were already spatially gridded, a climatology of mean annual swept area ratio was compiled (Fig. 4). 


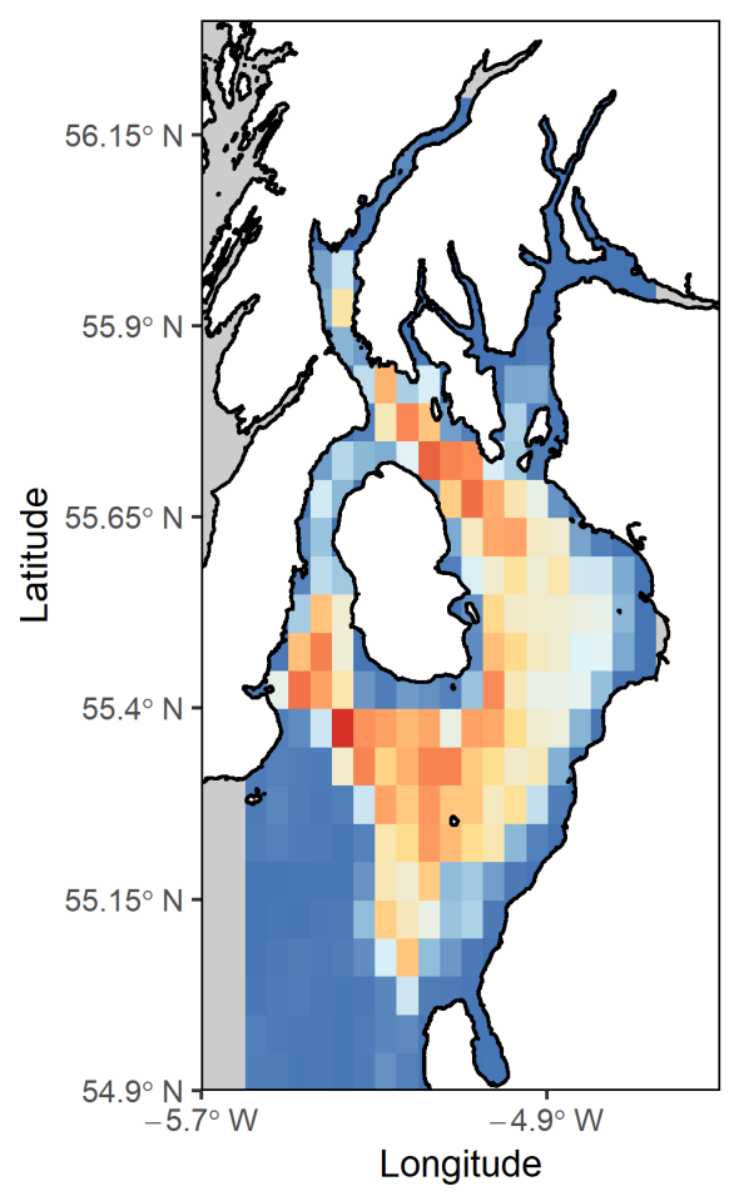

Figure 4 Mean annual swept area ratio (SAR) for the years 2009 - 2016. Spatial distribution of seabed abrasion pressure from fishing vessels with an overall length greater than $12 \mathrm{~m}$. Areas where no data is available are shown in grey.

\subsubsection{Seabed organic matter content}

Data on sediment organic carbon and nitrogen content and sediment fractions of mud, sand and gravel were requested from SEPA for the Firth of Clyde. SEPA measurements of organic carbon and nitrogen content were taken from the $<63 \mu \mathrm{m}$ grain size fraction rather than the whole sediment. Using these values directly would over-predict organic carbon and nitrogen as organic matter is expected to be overwhelmingly associated with the mud fraction (Wiesner et al., 1990). 
https://doi.org/10.5194/essd-2021-23

Preprint. Discussion started: 17 May 2021

(c) Author(s) 2021. CC BY 4.0 License.

(c) (i)

The organic matter content associated with the gravel fraction $(>2000 \mu \mathrm{m})$ was assumed to be negligible and the average density of carbon and nitrogen associated with the sand fraction for a range of marine sediments was calculated (see Appendix A). These estimates were then used to scale SEPA measurements of organic carbon and nitrogen to the whole sediment.

\subsection{Additional data collection}

185 Research cruises in the Firth of Clyde were carried out between 24 - 28 April and 13 - 17 October 2017 for the collection of additional seabed sediment geotechnical and nutrient content data. Respectively, 35 stations in the outer Firth of Clyde and 14 stations in the inner Firth of Clyde and sea lochs were sampled over the course of the two cruises. Measurements of seabed sediment grain size, and particulate organic carbon and nitrogen were carried out on seabed sediment samples collected using a $0.1 \mathrm{~m}^{2}$ Day grab. Sediment subsamples were taken from each grab sample using a 5 by $3.5 \mathrm{~cm}$ acrylic minicore tube and frozen immediately following collection aboard the research vessel at $-18{ }^{\circ} \mathrm{C}$ in sealable polyethylene bags for subsequent laboratory analysis. Sediment particulate organic carbon and nitrogen content were measured from freeze-dried Day grab subsamples using an EAS Costech 4020 Elemental Combustion Analyser. The remainder of the freeze-dried subsample was sieved for 10 minutes through a stack of 11.20, 8.00, 5.56, 3.35, 2.36, 2.00- and 1.40-mm mesh sieves mounted on a sieve shaker. The sediment fractions retained on each sieve were weighed to the nearest 0.1 milligram and further analysed using a Beckman Coulter LS230 Laser Diffraction Particle Size Analyser. The sieve and laser diffraction data were blended and summary statistics, including median grain size, $\%$ fractions of mud, sand and gravel, skewness and kurtosis, were calculated using GRADISTAT v8 (Blott and Pye, 2001).

Measurements of sediment permeability, porosity and grain size were made from undisturbed seabed sediment cores sampled using a Craib corer (Craib, 1965). Following collection, seabed sediment cores were refrigerated in the dark with loosely fitted caps, and analysis for permeability was carried out within eight hours of collection. Cores were trimmed to the top $10 \mathrm{~cm}$ of seabed sediment prior to analysis. The hydraulic conductivity $(K)$ of the top $10 \mathrm{~cm}$ of seabed sediment was measured via the falling head method (Klute and Dirksen, 1986). The decline in water level between two different hydraulic heads was recorded over a 2-hour interval and the hydraulic conductivity was calculated via:

$K=\log _{e}\left(\frac{H_{1}}{H_{2}}\right) \frac{a L}{A t}$

where $t$ is the time (s) taken for the level of the percolating fluid to decline between hydraulic head differences $H_{1}$ and $H_{2}(\mathrm{~m})$, $L$ and $A$ are the length (m) and cross-sectional area $\left(\mathrm{m}^{2}\right)$ of the sediment sample respectively, and $a$ is the cross-sectional area $\left(\mathrm{m}^{2}\right)$ of the water reservoir. The intrinsic permeability is related to the hydraulic conductivity via the expression:

$\kappa=\frac{K \eta}{\rho g}$

where $g$ is the acceleration due to gravity $\left(9.81 \mathrm{~m} \mathrm{~s}^{-2}\right), \rho$ is fluid density $\left(1027 \mathrm{~kg} \mathrm{~m}^{-3}\right)$ and $\eta$ is dynamic viscosity of the fluid $\left(1.48 \times 10^{-3} \mathrm{~kg} \mathrm{~m}^{-1} \mathrm{~s}^{-1}\right)$. Following the measurement of hydraulic conductivity, sediment cores were extruded from the acrylic tubes, sealed in polythene bags and frozen at $-12{ }^{\circ} \mathrm{C}$ for subsequent porosity and grain size analysis. Sediment was weighed 
https://doi.org/10.5194/essd-2021-23

Preprint. Discussion started: 17 May 2021

(c) Author(s) 2021. CC BY 4.0 License.

before and after drying in an oven at $105^{\circ} \mathrm{C}$ for 24 hours (Moore and Keller, 1984), and sediment porosity was calculated for each core slice via:

$\phi=\frac{V_{w}}{V_{T}}$

215 where $V_{T}$ is the volume of saturated sediment $\left(\mathrm{cm}^{3}\right)$ calculated from the thickness of the slice and the internal cross-sectional area of the acrylic core tube, and $V_{w}$ is the pore volume calculated with the expression:

$V_{w}=\frac{w w-d w}{\rho}$

where $d w$ and $w w$ are the dry and wet weights ( $\mathrm{g}$ ) of the sample, and $\rho$ is the water density taken to be $1 \mathrm{~g} \mathrm{~cm}^{-3}$ given that solutes are retained in the dried sediment. Grain size analysis was then carried out as previously described for sediment grab samples.

\subsection{Mapping seabed properties}

All data processing and statistical modelling was carried out using the R statistical program (R Core Team, 2019). Several seabed properties were modelled using Random Forest models and were fitted in the present study using the ranger package (v0.11.2) (Wright and Ziegler, 2017). It has the advantage of capturing complex non-linear relationships in the data and reducing the variance in model prediction, whilst being relatively insensitive to irrelevant explanatory variables (Hastie et al., 2009). Random Forest models have been applied to numerous marine mapping challenges, including the distribution of vulnerable benthic species (Portela et al., 2015), global patterns in seafloor biomass (Wei et al., 2010), the diversity and biomass of reef fish communities (Knudby et al., 2010), and the particle size fractions (Li et al., 2011; Stephens and Diesing, 2015) and organic carbon content (Diesing et al., 2017; Wilson et al., 2018) of seabed sediments.

230 Although implementations of Random Forest models typically carry out an internal cross-validation using 'out-of-bag' data, this does not account for spatial autocorrelation. To provide a more robust estimate of model prediction accuracy, a spatial cross-validation was run where data are binned at a resolution of $0.125^{\circ}$ Latitude and $0.25^{\circ}$ Longitude. A third of the data bins are randomly assigned as test data, the model is trained on the remaining data and evaluated against the test data. This process is repeated, and the model prediction error is averaged between successive iterations until the error stabilises. One thousand

235 iterations were used for the cross-validation of rock and sediment grain size fraction models, whereas 2000 iterations were used for the organic carbon and nitrogen models.

A suite of environmental variables to predict seabed properties, and capturing aspects of bathymetry, seabed topography and hydrodynamic flow, were calculated from a high-resolution unstructured-grid Finite-Volume Community Ocean Model (FVCOM) hydrodynamic model configured for the Firth of Clyde (Sabatino et al., 2016). The model was forced using a 240 combination of tidal, atmospheric, meteorological and hydrological data to capture tidal, wind and density-driven flow in the Firth of Clyde for the years 2005 and 2006, generating hourly estimates of current velocity over an irregular grid of triangular cells that provides higher spatial resolution close to the coast. A detailed description of the calibration and validation of the 
https://doi.org/10.5194/essd-2021-23

Preprint. Discussion started: 17 May 2021

(c) Author(s) 2021. CC BY 4.0 License.

(c) (i)

Clyde FVCOM hydrodynamic model is given by Sabatino et al. (2016). The full list of explanatory environmental variables used to predict seabed physical properties and sedimentary organic matter is given in Table 2.

Distance to coastline is taken to be the minimum Euclidean distance in metres between a given point and any point on the coastline and was calculated using high-resolution polygons of the Scottish coast and islands and the dist2Line function from the geosphere package (v1.5-10) (Hijmans, 2019). The annual minimum, mean and maximum bed shear stress and the annual minimum, mean and maximum depth-averaged current speed were calculated from predicted hourly values extracted from the Firth of Clyde hydrodynamic model run for two consecutive years (2005 and 2006). The seabed slope, standard deviation of the slope and topographic roughness were calculated following the methods used by Wilson et al. (2018). Seabed slope was calculated with the slope function from the SDMTools package (v1.1-221.1) (Van Der Wal et al., 2019), and the standard deviation of the slope and topographic roughness were calculated from slope and bathymetry respectively following the method of Cavalli et al. (2008).

These explanatory variables were mapped to an irregular grid of 39449 points with a spatial arrangement that corresponded to the locations of velocity estimates in the FVCOM unstructured grid. This eliminated the need to interpolate depth-averaged current velocity and bed shear stress outputs from the hydrodynamic model to a different grid arrangement.

Given the irregular arrangement of grid points, predicted maps are visualised using Dirichlet cells generated from the packages ggvoronoi (Garrett et al., 2019) and deldir (v0.1-16) (Turner, 2019). Maps and figures are generated in R using the ggplot2 package (Wickham, 2016).

\subsubsection{Rock distribution}

Coverage of BGS data did not extend into the Clyde estuary and sea lochs, and a Random Forest binary classification model was used to predict the distribution of hard substrate in these areas. To assemble a training data set, the irregular grid points containing the explanatory variables were classified as rock or non-rock within areas covered by BGS data. These were augmented by rock outcrop observations in the Clyde estuary digitised from Admiralty Charts. The environmental variables used to predict the presence of rock substrate are given in Table 2. Model performance was assessed via spatial cross-validation. Given the sparsity of rock observations, the bootstrapping of training and test data was constrained so that at least one instance of rock is present in both subsets.

Table 2 Explanatory environmental variables used to predict seabed physical properties and particulate organic carbon (POC) and nitrogen (PON) content. The annual minimum, mean and maximum modelled sea surface salinity and the mean annual swept area ratio by the fishing fleet were evaluated as explanatory variables for POC and PON but were not retained in the optimal model.

\begin{tabular}{|c|c|c|c|c|c|c|c|}
\hline Variable name & Units & Rock & $\begin{array}{l}\text { Grain size } \\
\text { fractions }\end{array}$ & $\begin{array}{l}\text { Median } \\
\text { grain } \\
\text { size }\end{array}$ & $\begin{array}{l}\text { Permeability } \\
\text { and porosity }\end{array}$ & POC & PON \\
\hline Latitude & $\circ$ & & $\mathrm{X}$ & & & & \\
\hline Longitude & $\circ$ & & $\mathrm{x}$ & & & & \\
\hline Depth & $\mathrm{m}$ & $\mathrm{x}$ & $\mathrm{x}$ & & & & \\
\hline Topographic roughness & - & $\mathrm{x}$ & $\mathrm{x}$ & & & $\mathrm{x}$ & \\
\hline
\end{tabular}




\begin{tabular}{|c|c|c|c|c|c|c|c|}
\hline Seabed slope & - & $\mathrm{x}$ & $\mathrm{x}$ & & & & \\
\hline Standard deviation of slope & - & $\mathrm{x}$ & $\mathrm{x}$ & & & & \\
\hline Distance to coastline & $\mathrm{m}$ & $\mathrm{x}$ & $\mathrm{x}$ & & & $\mathrm{x}$ & $\mathrm{X}$ \\
\hline Annual minimum current speed & $\mathrm{m} \mathrm{s}^{-1}$ & $\mathrm{x}$ & $\mathrm{x}$ & & & & \\
\hline Annual mean current speed & $\mathrm{m} \mathrm{s}^{-1}$ & $\mathrm{x}$ & $\mathrm{x}$ & & & & \\
\hline Annual maximum current speed & $\mathrm{m} \mathrm{s}^{-1}$ & $\mathrm{x}$ & $\mathrm{x}$ & & & & \\
\hline $\begin{array}{l}\text { Annual minimum bed shear } \\
\text { stress }\end{array}$ & $\mathrm{N} \mathrm{m}^{-2}$ & $\mathrm{x}$ & $\mathrm{x}$ & & & & \\
\hline Annual mean bed shear stress & $\mathrm{N} \mathrm{m}^{-2}$ & $\mathrm{x}$ & $\mathrm{X}$ & & & & $\mathrm{X}$ \\
\hline $\begin{array}{l}\text { Annual maximum bed shear } \\
\text { stress }\end{array}$ & $\mathrm{N} \mathrm{m}^{-2}$ & $\mathrm{x}$ & $\mathrm{x}$ & & & $\mathrm{x}$ & $\mathrm{x}$ \\
\hline Mean annual swept area ratio & - & & & & & & \\
\hline $\begin{array}{l}\text { Annual minimum surface } \\
\text { salinity }\end{array}$ & - & & & & & & \\
\hline Annual mean surface salinity & - & & & & & & \\
\hline $\begin{array}{l}\text { Annual maximum surface } \\
\text { salinity }\end{array}$ & - & & & & & & \\
\hline Mud content & $\%$ & & & $\mathrm{x}$ & $\mathrm{x}$ & $\mathrm{x}$ & $\mathrm{X}$ \\
\hline Sand content & $\%$ & & & $\mathrm{x}$ & & & \\
\hline Gravel content & $\%$ & & & $\mathrm{x}$ & & & \\
\hline Median grain size & $\mathrm{mm}$ & & & & $\mathrm{x}$ & & \\
\hline
\end{tabular}

\subsubsection{Sediment grain size fractions}

Sediment particle size fractions were mapped in terms of the proportion of mud, sand and gravel. Following methods given by Stephens and Diesing (2015), a coupled additive log-ratio transformation (Eq. 5 and Eq. 6) was used to couple the sediment fractions and ensure that the proportions summed to 1 .

$\log \left(\frac{\text { sand }}{\text { mud }}\right)=\log ($ sand $)-\log ($ mud $)$

$\log \left(\frac{\text { gravel }}{\text { mud }}\right)=\log ($ gravel $)-\log ($ mud $)$

Mud was used as the denominator within this transformation to accommodate MSS data that lacked measurements of the gravel fraction. Random Forest models were used to predict the log-ratios of sand to mud and gravel to mud from environmental variables listed in Table 2. Spatial cross-validation of the model was carried out to test the accuracy of backtransformed predictions of sediment mud, sand and gravel fractions.

Produced maps were further validated against independent sediment data collected during the April and October 2017 research cruises. Bilinear interpolation was used to predict mud, sand and gravel content at sampled stations and the variance explained by the model was calculated for the station-averaged observed data. 
https://doi.org/10.5194/essd-2021-23

Preprint. Discussion started: 17 May 2021

(c) Author(s) 2021. CC BY 4.0 License.

(c) (i)

\subsubsection{Median grain size}

285 A generalised additive model (GAM) of the form: $\log _{10}\left(D_{50}\right) \sim s(m u d$, sand, gravel) was used to relate median grain size to sediment fractions. The predictive accuracy of the GAM fit was assessed through Leave-One-Out Cross-validation (LOOCV). A map of median grain size for the Firth of Clyde was predicted from the fitted GAM using the previously generated maps of sediment mud, sand and gravel content.

\subsubsection{Permeability and porosity}

290 The relationships between sediment permeability and median grain size for the top $10 \mathrm{~cm}$ of sediment was expressed via a log$\log$ form of the equation described by Wilson et al. (2018), modified to incorporate an intercept:

$\log _{10}$ (permeability) $=\log _{10}\left(10^{a} D_{50}^{b}+c\right)$

Relationships were also defined between sediment permeability and mud content in the top $10 \mathrm{~cm}$ of seabed sediment using a $\log -\log$ function. Sediment porosity measurements were supplemented by data from literature and fitted to the logistic function

295 given by Wilson et al. (2018):

$\log \phi=p_{1}+p_{2}\left(\frac{1}{1+e^{\frac{-\left(\log _{10} D_{50}-p_{3}\right)}{p_{4}}}}\right)$

Equations were fitted to data using the Nelder-Mead algorithm to minimise the root sum of square error (RSS). Maps of sediment permeability and porosity for the Firth of Clyde were then generated by applying the fitted equations to the maps of median grain size.

\subsubsection{Natural seabed abrasion}

Following Wilson et al. (2018), sediment mobilisation by near-bed water movement was predicted by the Shields relationship. Rates of natural seabed abrasion were then expressed in terms of the annual percentage of time that sediment motion occurs (hereafter referred to as sediment mobility). The hourly near-bed shear stress $\left(\tau_{b}\right)$ and occurrence of sediment movement were calculated for each point on the unstructured grid of the Clyde using the bedshear package (Wilson and Heath, 2019). This hourly binary classification for sediment movement was then summarised to an annual proportion for each point and mapped.

\subsubsection{Seabed organic matter content}

The particulate organic carbon and nitrogen content of seabed sediments in the Firth of Clyde were modelled using Random Forests. To assess the potential influence of organic matter loading in river freshwater input on the organic carbon and nitrogen content of seabed sediments, estimated annual minimum, mean and maximum surface salinity was extracted from the Firth of

310 Clyde hydrodynamic model and used as a potential explanatory variable. Mean annual fishing swept area ratio was also included as a potential explanatory variable to account for the possible winnowing effect of frequent trawling disturbance on sedimentary organic matter (Palanques et al., 2014; Pusceddu et al., 2014). Although Random Forests are generally robust to 
https://doi.org/10.5194/essd-2021-23

Preprint. Discussion started: 17 May 2021

(c) Author(s) 2021. CC BY 4.0 License.

(c) (1)

the presence of highly correlated explanatory variables, model performance may be impacted in smaller datasets (e.g. Li et al., 2011). Recursive Feature Elimination (RFE) is a popular method to select a subset of relevant uncorrelated variables from a

315 large number of noisy or highly-correlated variables by iteratively fitting a Random Forest model and removing the least important ranked variable (Gregorutti et al., 2017). Given the relatively small number of sediment organic carbon and nitrogen measurements available, a variation of Recursive Feature Elimination (RFE) was used to improve model prediction. Spatial cross-validations were run for the full model and for single removals of each environmental variable. The variable whose removal led to the greatest reduction in mean squared error in model prediction was dropped and the process repeated for the reduced suite of variables. This was repeated until the no further minimisation of model error was achieved through the removal of further environmental variables.

\subsubsection{Standing stock of organic carbon and nitrogen in surficial sediments}

Using the map of porosity for the Firth of Clyde, the dry bulk density of the sediment $\left(\rho_{d}\right)$ was calculated from sediment porosity $(\phi)$ assuming a sediment density $\left(\rho_{s}\right)$ of $2.65 \mathrm{~g} \mathrm{~cm}^{-3}$ via:

$325 \rho_{d}=(1-\phi) \rho_{s}$

The masses of organic carbon and nitrogen were then calculated as the product of the proportion by mass of the organic element in dry sediment, dry bulk density, sediment depth and polygon area.

\section{Results}

\subsection{Rock distribution}

330 The distribution of hard substrate in the Firth of Clyde is shown in Fig. 5. Random Forest model predictions suggest that the distribution of hard substrate within the inner Firth of Clyde and sea lochs is limited and largely confined to coastlines. The area-under-the-curve (AUC) for spatial cross-validation of model predictive performance was 0.628. 


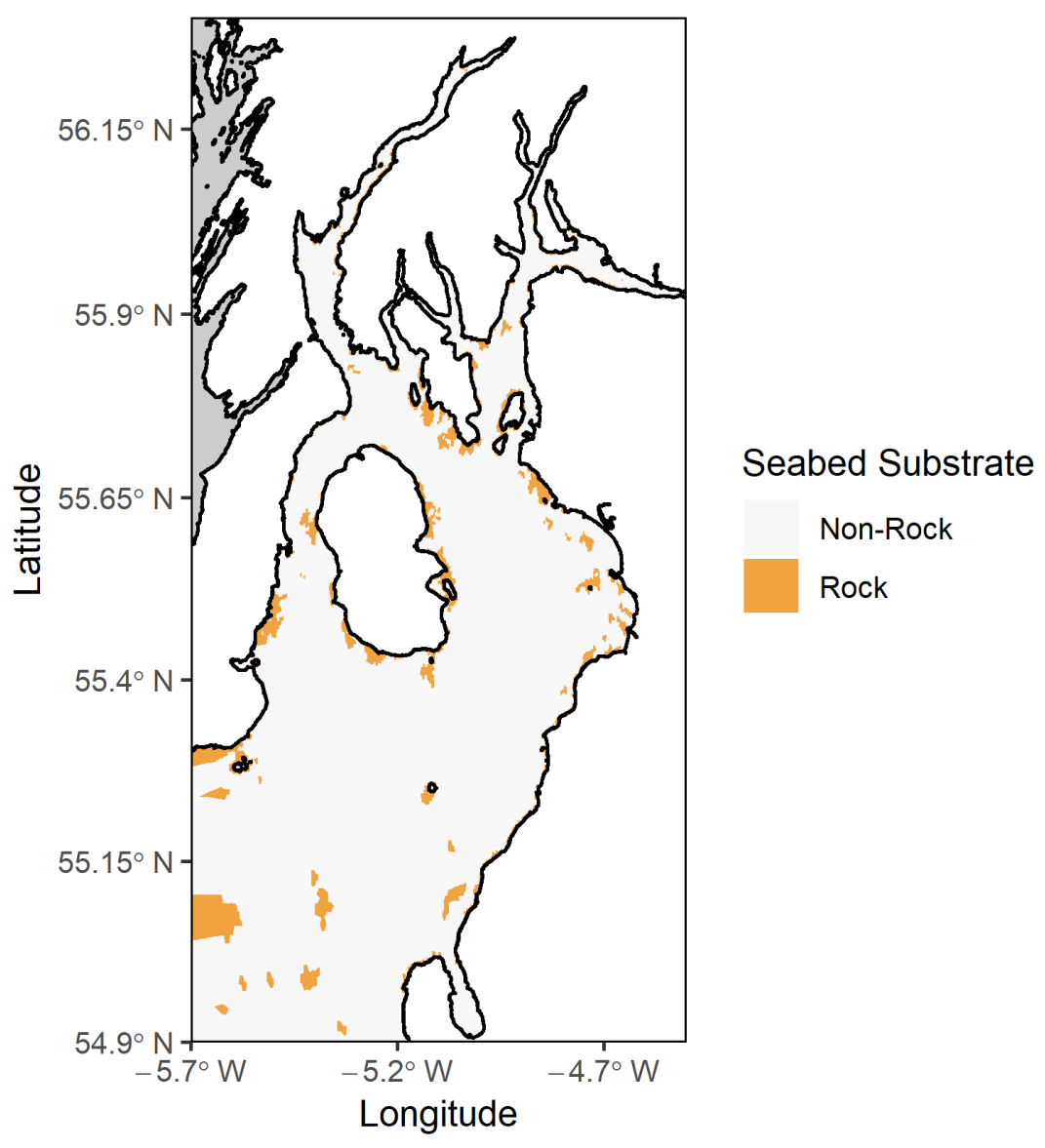

Figure 5 Distribution of hard substrate in the Firth of Clyde according to BGS data layers and Random Forest model predictions generated for areas lacking data - the inner Firth of Clyde and sea lochs.

\subsection{Sediment grain size fractions}

Maps of predicted percentages of mud, sand and gravel in the Firth of Clyde are shown in Fig. 6. Extensive areas in the outer Firth of Clyde, including the Arran Deep and Kilbrannan Sound, consist of sediments dominated by the mud fraction, with close to $100 \%$ of particles having a diameter $<63 \mu \mathrm{m}$. In the inner Firth of Clyde and sea lochs, the mud fraction dominates in the sediments of upper Loch Fyne, Holy Loch, and Loch Long. In contrast, sand dominates in coastal areas, especially along the Ayrshire coast, and on the Great Plateau, whereas the percentage of gravel in Clyde Sea sediments is almost universally low. 

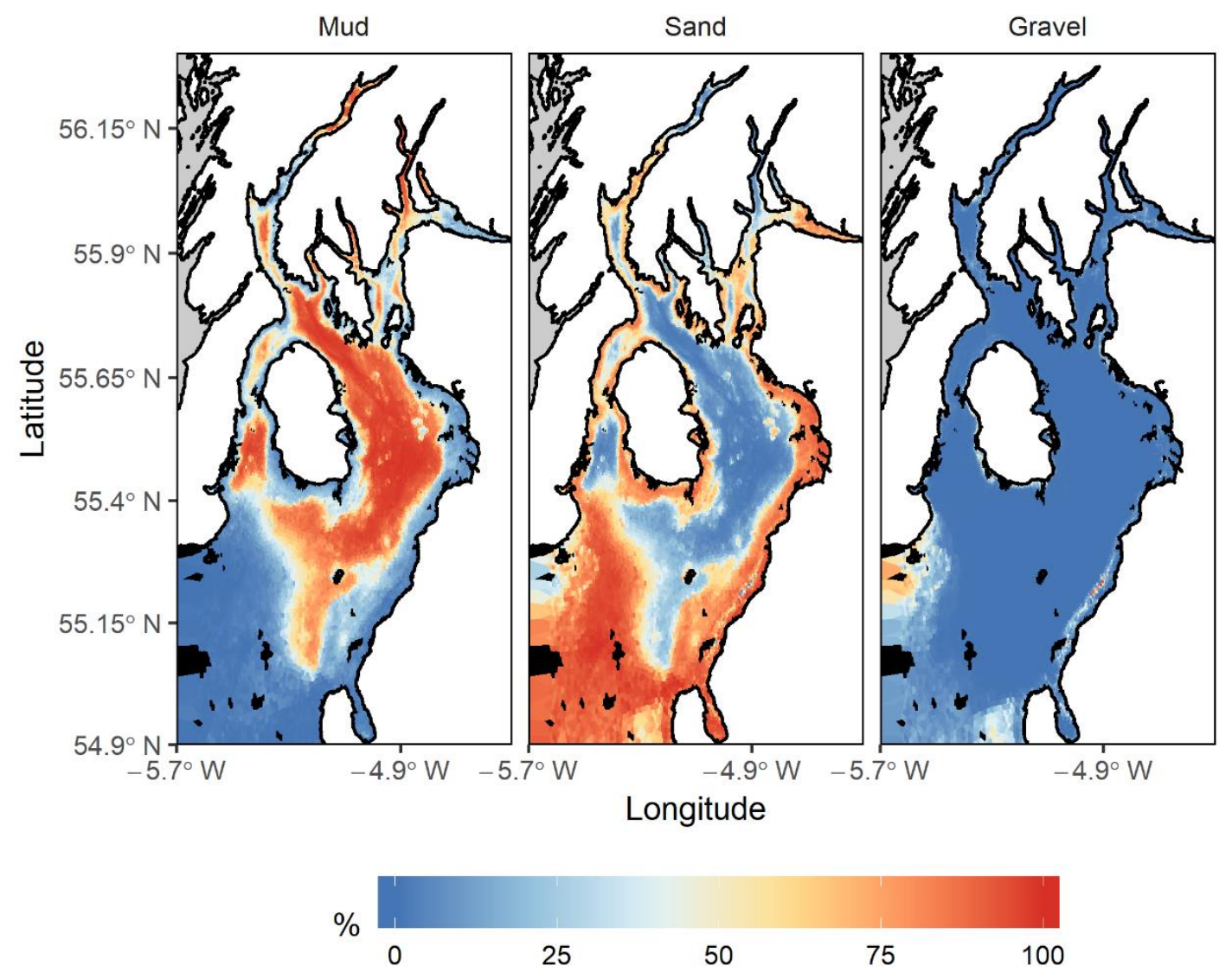

Figure 6 Mapped percentages of mud, sand and gravel within Firth of Clyde sediments predicted from Random Forest models.

Random Forest models capture the variation in mud and sand content well. Spatial cross-validation results yield $\mathrm{R}^{2}$ values of $0.611,0.382$ and 0.321 for mud, sand and gravel, respectively. Results from the map validation against independent data are shown in Fig. 7 and demonstrate good predictability of mud and sand percentages. $\mathrm{R}^{2}$ for mud and sand content from map validation against independent data were higher $\left(R^{2}\right.$ mud $=0.635, R^{2}$ sand $\left.=0.611\right)$. However, prediction of gravel content is considerably poorer $\left(\mathrm{R}^{2}\right.$ gravel $\left.=0.08\right)$. 

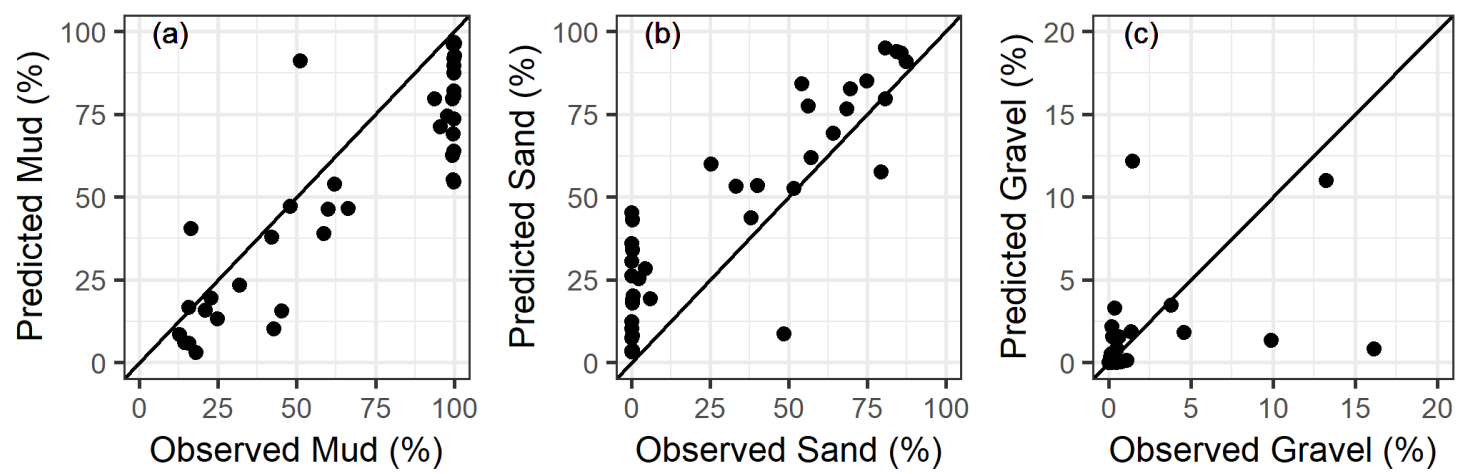

Figure 7 Comparison of predicted and observed percentages of (a) mud, (b) sand and (c) gravel in Firth of Clyde seabed sediments.

\subsection{Median grain size}

Leave-one-out cross-validation (LOOCV) of the GAM shows good agreement between predicted and observed measurements of sediment median grain size (Fig. 8). The model accounted for $90.76 \%$ of the variance in the data.

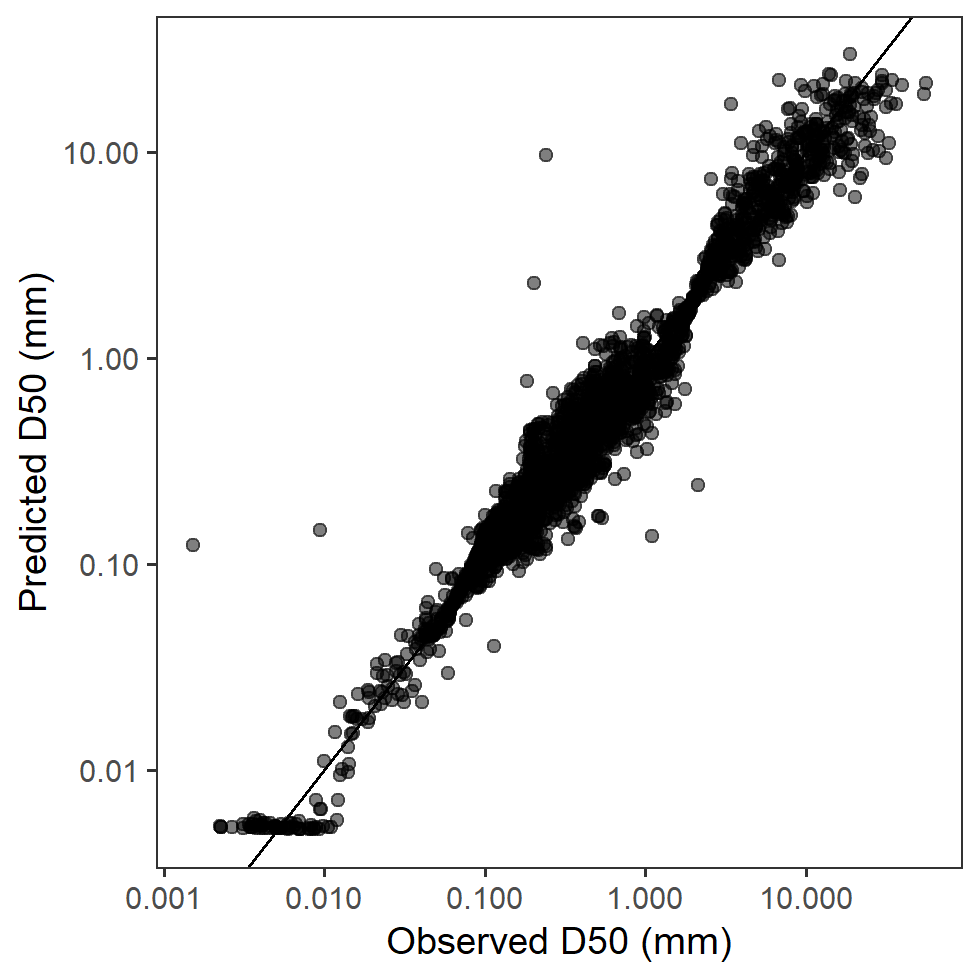

Figure 8 Leave-one-out cross-validation results showing predicted and measured values of median grain size for a dataset comprising samples collected from cruises in the Firth of Clyde in April and October 2017 and supplemented with data from the North Sea, Celtic Sea and English channel collected by CEFAS and MSS $(n=3244)$. Note $\log _{10}$ scale. 
https://doi.org/10.5194/essd-2021-23

Preprint. Discussion started: 17 May 2021

(c) Author(s) 2021. CC BY 4.0 License.

(c) (1)

Following spatial variation in the fractions of mud and sand, the median grain size of seabed sediments in the Firth of Clyde is lowest in smallest in the Arran Deep and Inchmarnock Water and largest in the shallow waters along the Ayrshire coast and the Great Plateau (Fig. 9).
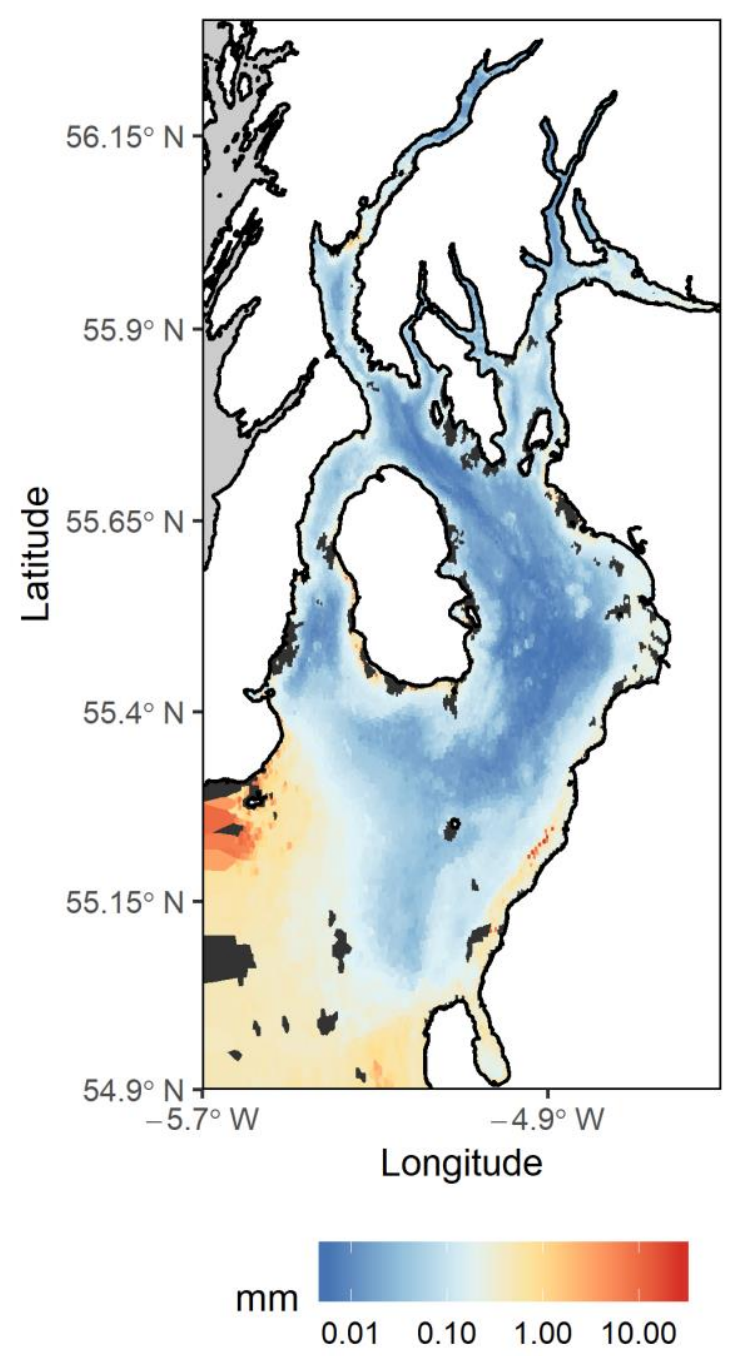

Figure 9 Mapped predictions of median grainsize for seabed sediments in the Firth of Clyde.

\subsection{Permeability and porosity}

365 The combined permeability dataset suitably covered a range of sediment types ranging from very fine-grained sediment to sandy sediments. Sediment permeability in the Firth of Clyde is well predicted by both the median grain size and $\%$ mud 
https://doi.org/10.5194/essd-2021-23

Preprint. Discussion started: 17 May 2021

(c) Author(s) 2021. CC BY 4.0 License.

(c) (i)

content (Fig. 10). The fitted relationships with mud and median grain size capture $82.3 \%$ and $91.5 \%$ of the variance in the data, respectively.
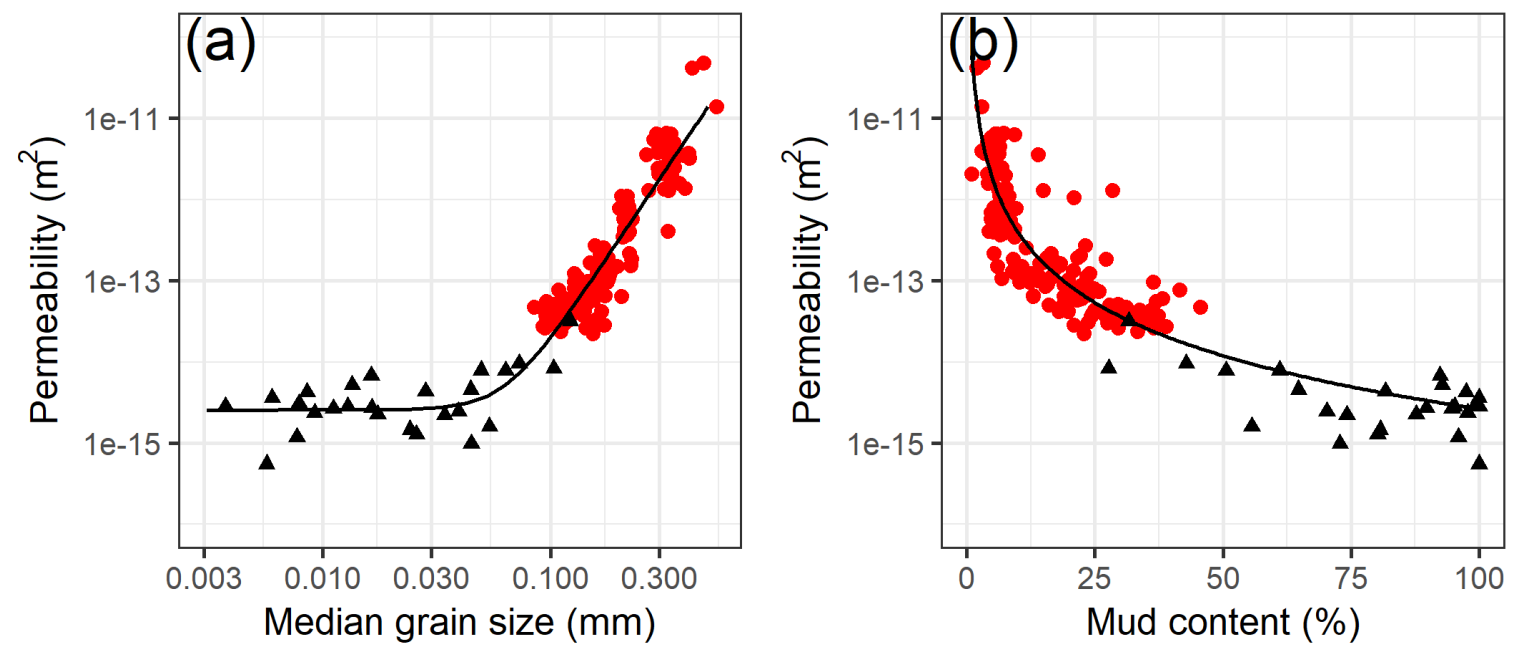

\section{Source $\Delta$ Clyde $\bullet$ Stonehaven}

370 Figure 10 Relationship between sediment permeability $\left(\mathrm{m}^{2}\right)$ and (a) median grain size (mm) and (b) \% mud content for measurements from the Firth of Clyde (black triangles) and samples from the North Sea analysed by Serpetti et al. (2016) (red points). Fitted relationships for the combined data are shown by a solid line. Note $\log _{10}$ scale.

The fitted sediment permeability relationships with median grain size and mud content are given by:

$\log _{10}$ (permeability $)=\log _{10}\left(10^{-9.5659} D_{50}^{4.1877}+2.5634 \times 10^{-15}\right)$

$\log _{10}$ (permeability) $=-2.171 \log _{10}(\mathrm{mud})-10.232$

Porosity is predicted by median grain size (Fig. 11). The parameters for the fitted logistic function for the relationship in the top $10 \mathrm{~cm}$ of seabed sediment are shown in Table 3. 


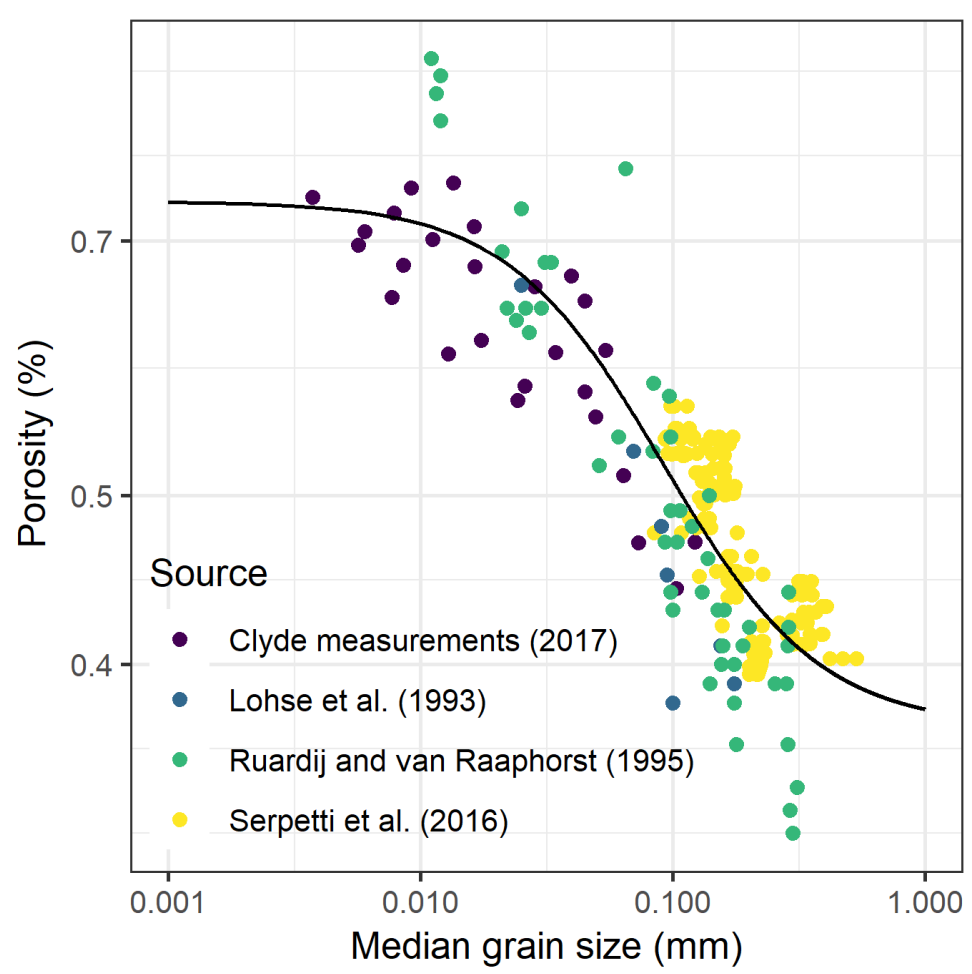

Figure 11 Relationship between sediment porosity $(\%)$ and median grain size $(\mathrm{mm})$ for the top $10 \mathrm{~cm}$ seabed sediment on a log 10 scale.

Table 3 Fitted parameter values for the logistic relationship between sediment porosity and median grain size in the top $10 \mathrm{~cm}$ of seabed sediment.

\begin{tabular}{ll}
\hline Parameter & Value \\
\hline $\mathrm{p}_{1}$ & -0.435 \\
$\mathrm{p}_{2}$ & 0.302 \\
$\mathrm{p}_{3}$ & -1.035 \\
$\mathrm{p}_{4}$ & -0.314 \\
\hline
\end{tabular}

The relationship between sediment permeability and mud content, rather than median grain size, was chosen to map the 385 distribution of seabed sediment permeability in the Firth of Clyde (Figure 12a) because the prediction dataset is one step closer to measured data. The vast majority of the Firth of Clyde is dominated by sediments having a permeability $<10^{-12} \mathrm{~m}^{2}$. This implies that sediments are impervious and solute exchange between the seabed and water column is diffusion-mediated. 

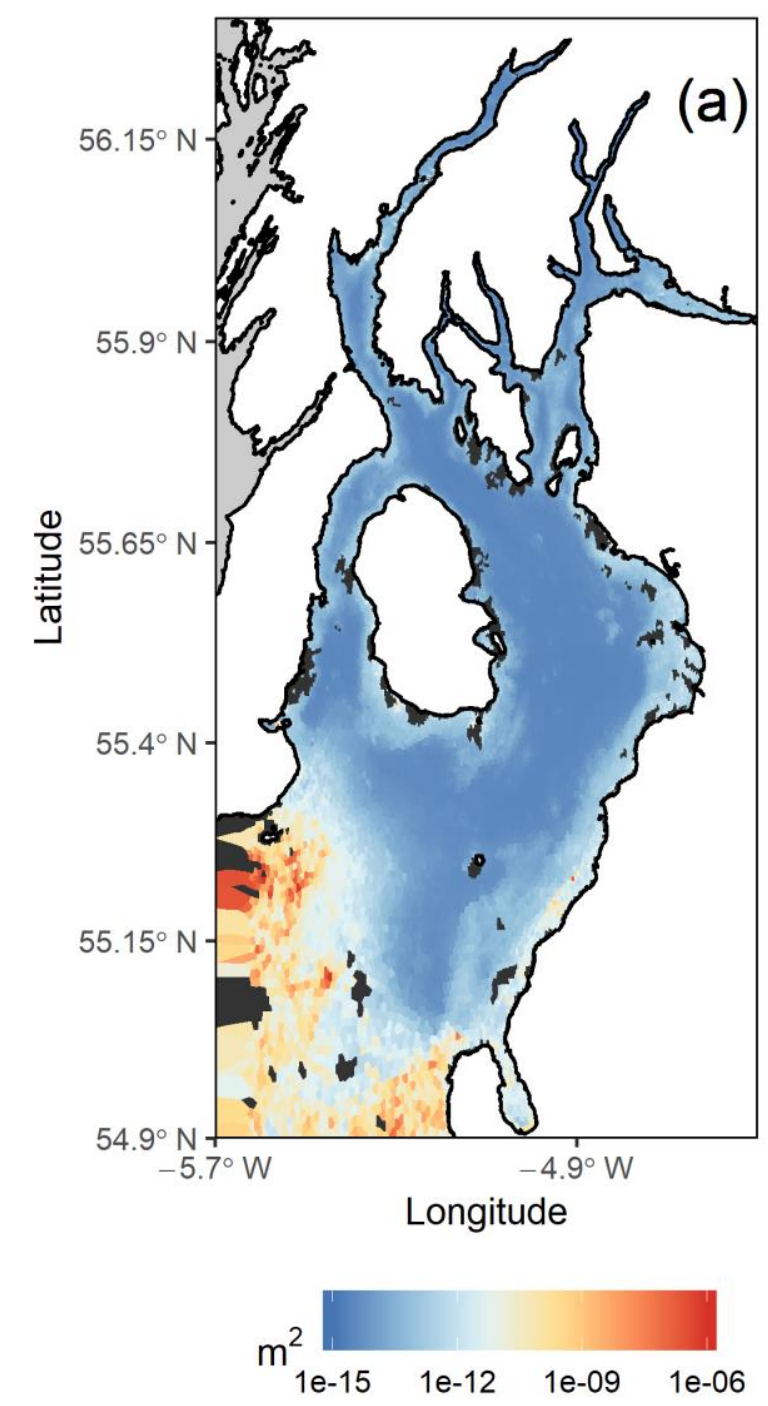
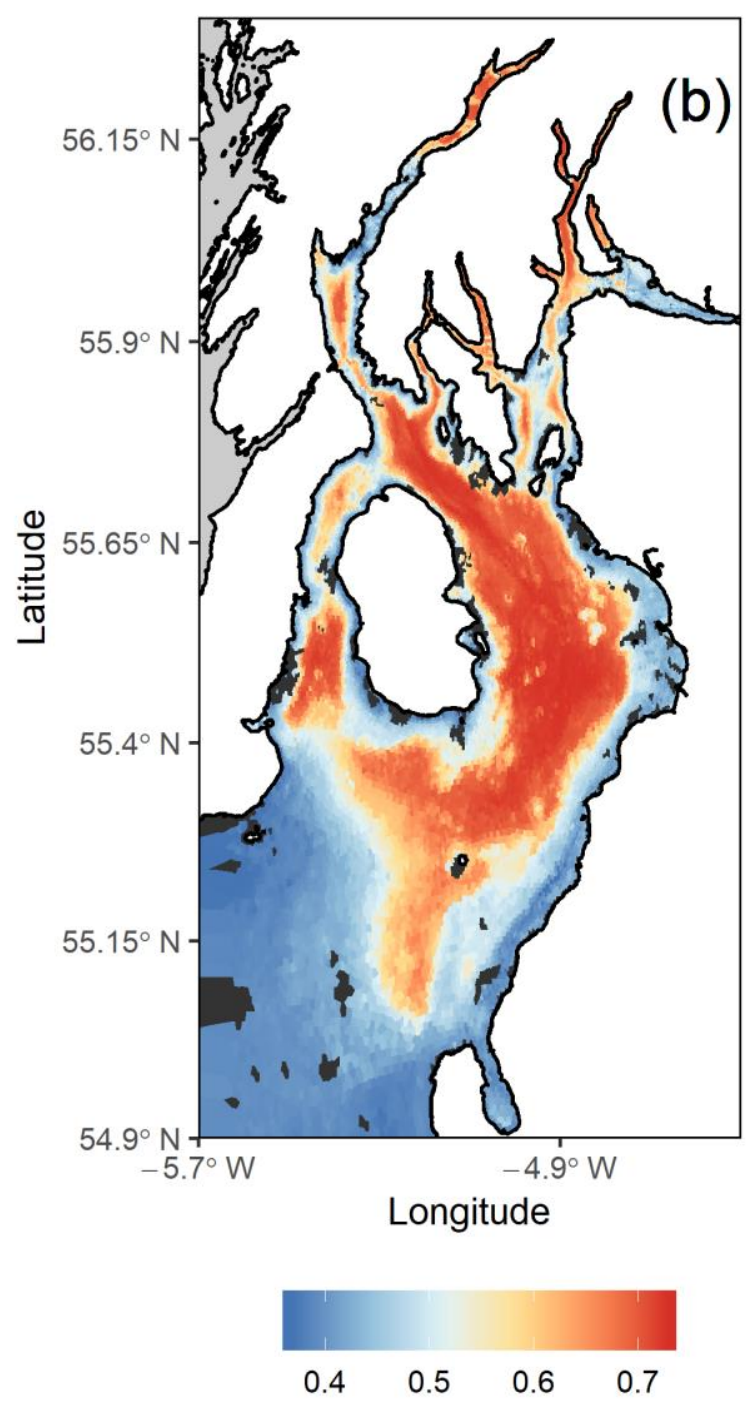

Figure 12 Mapped predictions of (a) sediment permeability and (b) sediment porosity in the Firth of Clyde. Seabed consisting of hard substrate or sediments with a predicted permeability greater than $1 \times 10^{-6} \mathrm{~m}^{2}$ are shown as black areas. Permeability predictions were generated from the map of percentage mud content in seabed sediments. Porosity was predicted from the map of median grain size in the Firth of Clyde.

\subsection{Natural seabed abrasion}

Extensive areas of the Clyde Sea, particularly Inchmarnock Water, the Inner Firth of Clyde and Loch Fyne appear to experience negligible annual sediment movement (Fig. 13). Sediment moves for up to $25 \%$ of the year in some areas of the Outer Firth. 

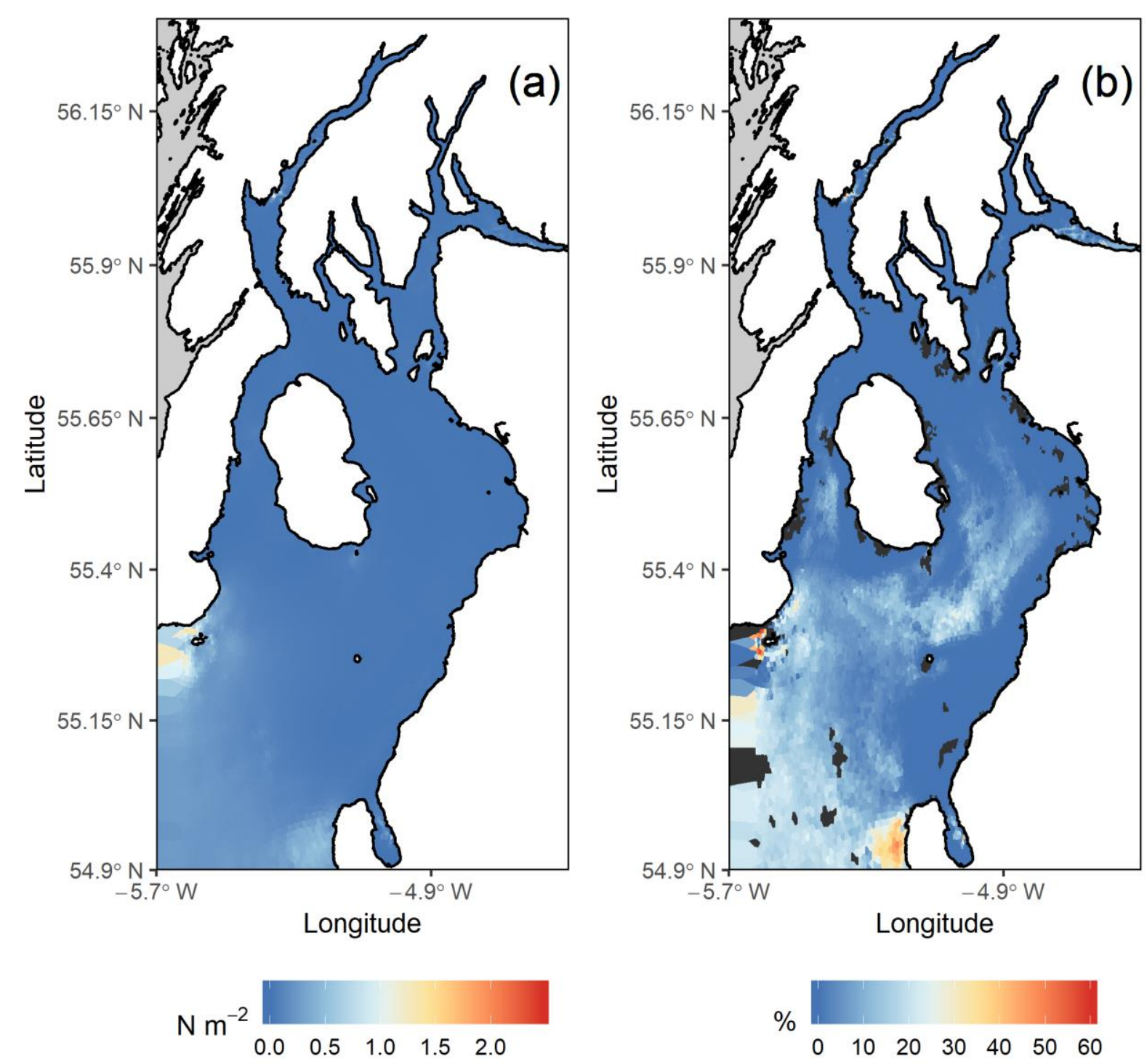

Figure 13 Mapped predictions of (a) annual mean bed shear stress and (b) sediment mobility in terms of the annual percentage of time that sediment motion occurs in the Firth of Clyde.

\subsection{Sediment organic matter content}

Cross-validated RFE substantially improved model predictions for both organic carbon and nitrogen. The initial models of organic carbon and nitrogen each contained 16 predictors and had a cross-validation $\mathrm{R}^{2}$ of 0.557 and 0.685 , respectively. Optimal models for particulate organic carbon and nitrogen each comprise four environmental variables, shown in Table 2, and have an $\mathrm{R}^{2}$ of 0.705 and 0.827 , respectively. 
https://doi.org/10.5194/essd-2021-23

Preprint. Discussion started: 17 May 2021

(c) Author(s) 2021. CC BY 4.0 License.

Maps of predicted \% organic carbon and nitrogen per gram dry weight sediment are shown in Fig. 14. Although salinity was inner firth sediments in proximity to sources of freshwater run-off.

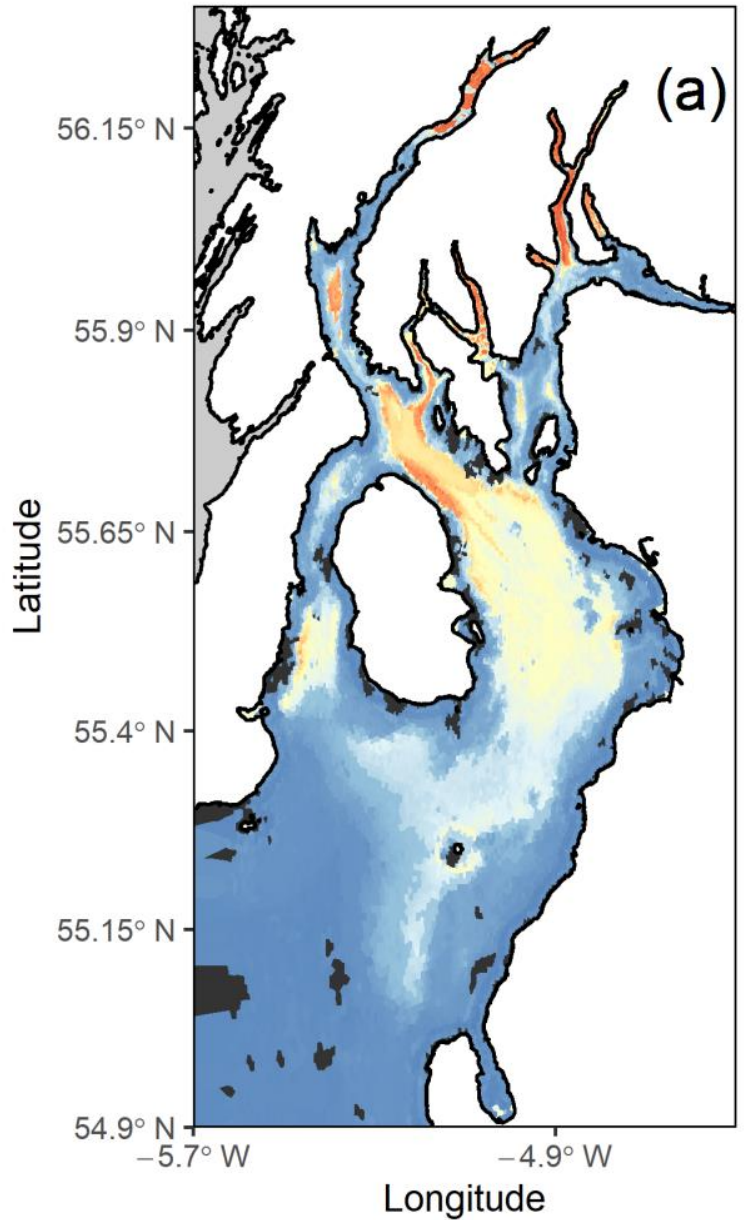

POC \% dw

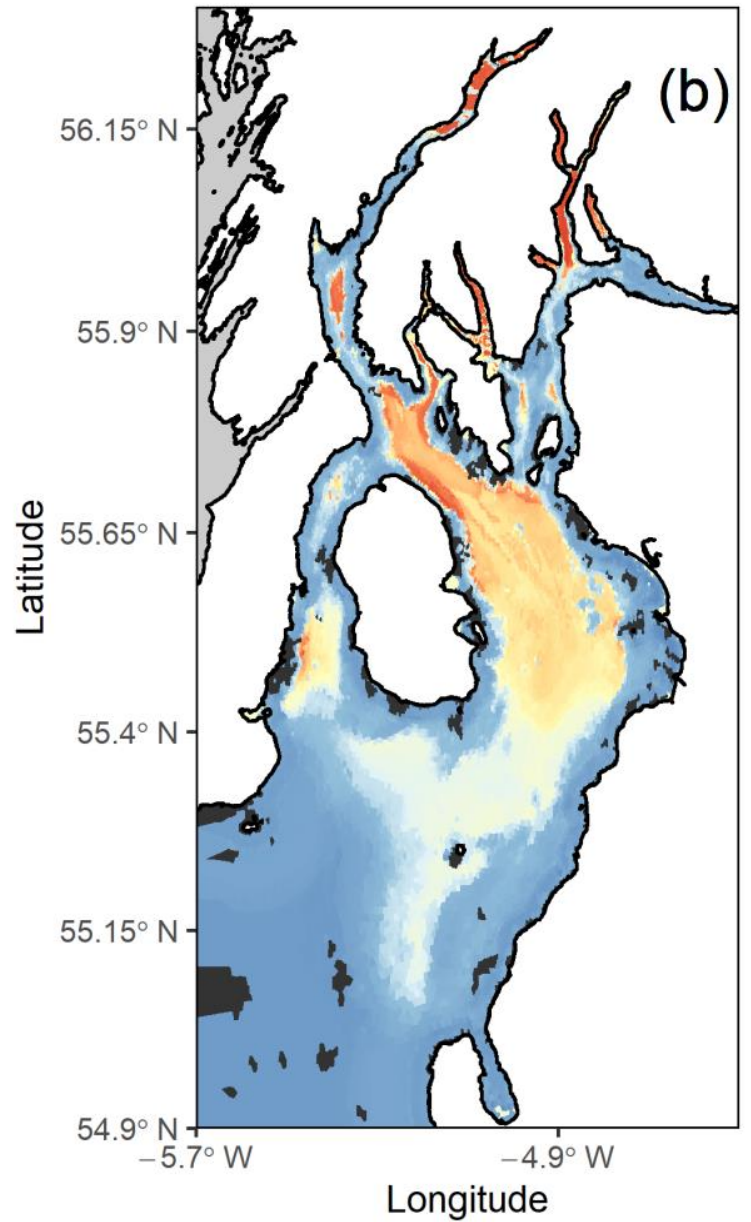

PON \% dw

Figure 14 Maps of predicted \% dry weight sediment (a) organic carbon and (b) organic nitrogen content within the top $10 \mathrm{~cm}$ of seabed in the Firth of Clyde.

Deviations from the Redfield ratio are seen in areas close to sources of terrestrial organic matter input (Inner Firth, Loch Fyne, Ayrshire coast) (Fig. 15). By calculating the bulk density of the sediment, the total mass of organic carbon and nitrogen in the top $10 \mathrm{~cm}$ of Firth of Clyde sediments estimated as 3.4224 and 0.3277 million tonnes, respectively. 


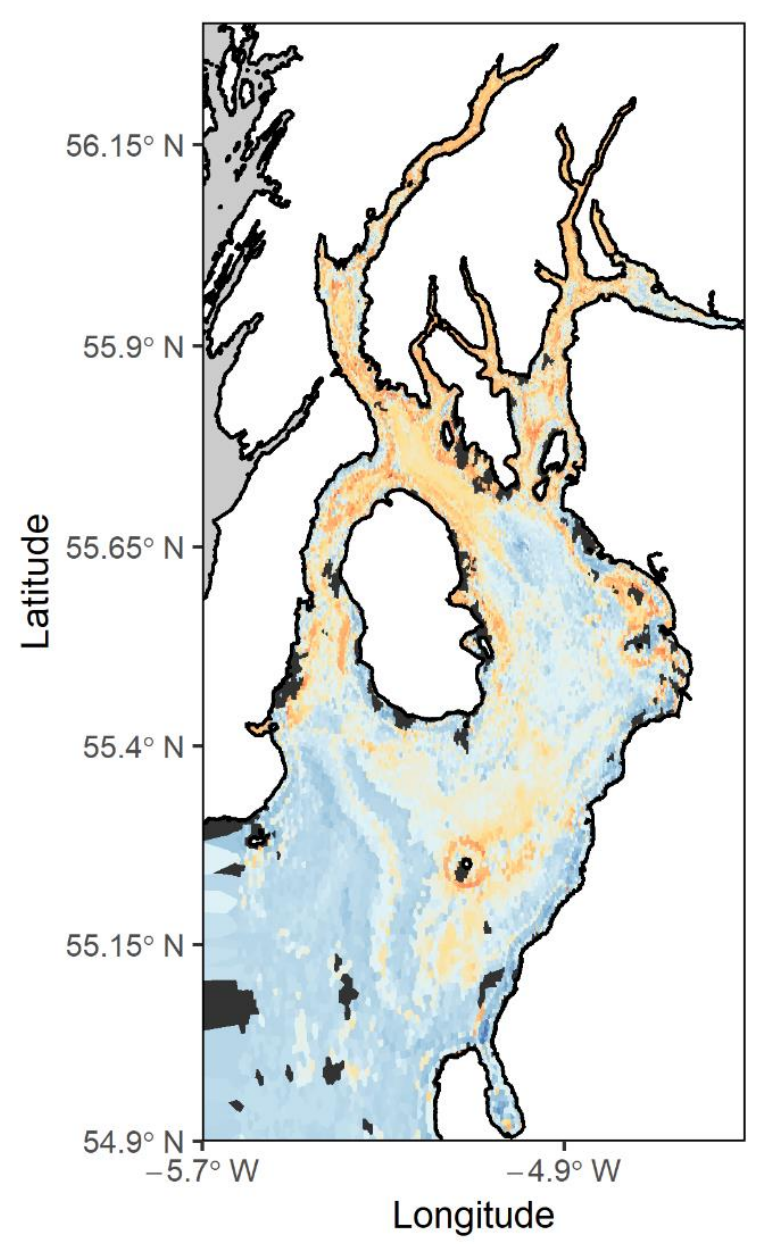

C:N molar ratio

510152025

Figure 15 Variation in the predicted organic carbon-nitrogen molar ratio.

\section{Discussion}

The maps of surficial sediment grain size fractions, whole-sediment median grain size, permeability, porosity, whole-sediment organic carbon and nitrogen content, and seabed natural disturbance presented in this study fill a current data gap for the Clyde. The variable spatial resolution allowed by the irregular grid arrangement suitably captures the fine-scale transition from coarser-grained sediment close to the coast to fine-grained sediments in deeper offshore waters. 
https://doi.org/10.5194/essd-2021-23

Preprint. Discussion started: 17 May 2021

(c) Author(s) 2021. CC BY 4.0 License.

420 Confidence in the predicted distributions of seabed mud, sand, organic carbon and nitrogen content is high, with validation procedures showing that the maps accounted for $\sim 60 \%$ of the variation in the independent data. However, the fraction of gravel in samples was low or negligible in most samples, and this is reflected in the poor confidence implied by the validation results.

The spatial distribution of organic carbon in the surficial sediments of the Clyde and the predicted molar ratios of carbon and nitrogen agree remarkably well, at a coarse scale, with patterns reported by Pearson et al. (1986). This may indicate that spatial patterns of sediment organic carbon and nitrogen are a relatively stable feature of the Clyde. The organic enriched muddy sediments in upper Loch Fyne, Loch Striven and the Kyles of Bute, the inner Clyde sea lochs, and the Inchmarnock basin coincide with areas of very low seabed disturbance. This may indicate that enrichment patterns are due to long-term organic matter deposition over eutrophic seabed. Although mud content was the most important predictor of organic carbon and nitrogen, corroborating previous work (Diesing et al., 2017; Wilson et al., 2018), this relationship was strongly dependent on other environmental variables, indicating that organic matter - sediment type relationships cannot be generalised across different regions.

Conversely, measurements of sediment permeability in the Clyde map onto median grain size relationships established for the North Sea and extend these relationships to finer-grain sediments. The updated relationships may be applied to a wide range

435 of sediment types collected from diverse marine coastal regions. A new relationship with the percentage mud content in sediment is presented to allow the prediction of permeability in mud-rich sediments.

Contrasting with patterns found by Wilson et al. (2018) in the North Sea, the overall high mud content of Clyde marine sediments leads to large seabed areas with a predicted sediment permeability well below $10^{-12} \mathrm{~m}^{2}$. Despite the expectation that shallow coastal sands would have permeabilities exceeding this threshold (Serpetti et al., 2016; Wilson et al., 2008), this was 440 only observed for limited areas of the South Ayrshire coast.

The mass of organic carbon in the surficial sediments of the Clyde was calculated to be 3.42 million tonnes within a $3739 \mathrm{~km}^{2}$ area. This suggests that the density of organic carbon in the Clyde within the top $10 \mathrm{~cm}$ of marine sediments may have been underestimated in work carried out to-date to catalogue stocks of organic carbon in Scottish coastal and shelf sediments (Burrows et al., 2014; Smeaton et al., 2020). For instance, the area covered by the Firth of Clyde is < $1 \%$ of Scotland's mapped 445 extended Exclusive Economic Zone (EEZ; 554,755 km²), yet surficial sediment organic carbon stocks calculated in the present study are $1.5 \%$ of the total organic carbon stock in the EZZ calculated by Smeaton et al. $(2020 ; 221 \mathrm{Mt})$. Given that the produced maps do not provide any estimate of sediment volume beyond the top $10 \mathrm{~cm}$, direct comparisons with studies that estimate total carbon stocks are difficult (e.g. Smeaton et al., 2016).

The frequency of seabed trawling disturbance, estimated via the mean annual swept area ratio, was not a predictor of sediment 450 of organic carbon or nitrogen in the Clyde. Hence, large-scale redistribution of organic matter due to transport of resuspended sediments reported by Pusceddu et al. (2014) for deep sea continental slopes is not observed in this shallow coastal marine system. Nevertheless, this does not imply that sedimentary organic matter is unaffected by the periodic resuspension of seabed sediments by the passage of demersal trawl gear. More detailed geochemical studies addressing the deposition, 
https://doi.org/10.5194/essd-2021-23

Preprint. Discussion started: 17 May 2021

(c) Author(s) 2021. CC BY 4.0 License.

(c) (i)

remineralisation and burial rates of organic matter are needed to provide a more complete assessment of the impact of trawling activity on carbon sequestration and storage in the marine sediments of the Firth of Clyde. Nevertheless, the maps presented here will contribute to these efforts. Coupled with mapped distributions of anthropogenic and natural seabed abrasion pressure, these maps are expected to be particularly useful for the assessment of seabed sensitivity to changes in disturbance regime and the maintenance of seafloor integrity.

\subsection{Limitations}

460 A key challenge in mapping Clyde sediment was the large variation in the availability of high-quality data on measurements sediment properties and of sediment properties across the range of environmental gradients represented in the region. Therefore, whole-sediment median grain size measurements from surrounding shelf seas were used to parameterise a statistical relationship between the whole-sediment median grain size and fractions of mud, sand and gravel. Additionally, there is limited good data on the fine-scale distribution of rocky outcrops and hard substrata for coastal seabed around the UK, including the

465 Firth of Clyde. The available data were in the form of polygons with limited information to distinguish between rocks, boulders and rock covered by a layer of sediment. More work is needed to refine these maps. The maps assume that no changes in distribution of sediment properties occurred as a result of any changes in disturbance regime over time. This assumption is supported by very low tidal currents over much of the Clyde (Davies et al., 2004), and fact that fishing pressure was not retained as a predictor of organic carbon and nitrogen concentration in Clyde sediments. Additional work is needed to define

470 permeability and grain size relationships in coarser sediments with a median grain size greater than $0.6 \mathrm{~mm}$. Hence, sediment permeability estimates greater than $10^{-11} \mathrm{~m}^{2}$ may be unreliable. Nevertheless, this constitutes a small fraction of the mapped area.

\section{Data availability}

Mapped data products are available in csv and netCDF format from: https://doi.org/10.15129/2003faa2-ee93-4c11-bb1648485f5f136d (Heath and Pace, 2021).

\section{Author contributions}

MP, MH, HS, DB and DS designed the analysis. MP, DB and HS collected samples and carried out laboratory analysis of sediments. MP and HS carried out compilation of data and modelling. MP drafted the manuscript, and all authors contributed to the writing of the manuscript. 
https://doi.org/10.5194/essd-2021-23

Preprint. Discussion started: 17 May 2021

(c) Author(s) 2021. CC BY 4.0 License.

(c) (i)

\section{Competing interests}

The authors declare that no competing interests are present.

\section{Acknowledgements}

We thank Jamie Reid and Myles O’Reilly (SEPA) for marine sediment data for the Firth of Clyde, Dan Edwards (JNCC) for access to swept-area ratio data, and Natalia Serpetti for access to disaggregated sediment permeability and porosity 485 measurements. We are grateful to Eric Dalgarno, Gerald McAllister, Melinda Choua and the skippers and crews of RV Alba na mara and RV Sir John Murray for facilitating the collection and processing of samples, and to Colin Abernethy and Sharon McNeill (SAMS) for help in the laboratory analysis of samples. We thank Robert Wilson for numerous insightful discussions on the analysis and mapping of coastal marine sediments. Research vessel time was provided by Marine Scotland Science. This work received funding from the MASTS pooling initiative (The Marine Alliance for Science and Technology for

490 Scotland) and NatureScot and their support is gratefully acknowledged. MASTS is funded by the Scottish Funding Council (grant reference HR09011) and contributing institutions. 
https://doi.org/10.5194/essd-2021-23

Preprint. Discussion started: 17 May 2021

(c) Author(s) 2021. CC BY 4.0 License.

(c) (1)

\section{Appendix A: Scaling mud-fraction organic matter content to the whole-sediment}

If the organic matter content associated with the gravel fraction $(>2 \mathrm{~mm})$ is negligible, the $\%$ particulate organic carbon content

495 (POC) of the whole sediment is given by:

$P O C=\frac{m_{\text {mud }}+m_{\text {sand }}}{p_{\text {mud }}+p_{\text {sand }}} \cdot 100$

Where $m_{m u d}$ and $m_{\text {sand }}$ are the masses of organic carbon respectively associated with the proportions of mud $\left(p_{m u d}\right)$ and sand $\left(p_{\text {sand }}\right)$. If the POC and mass fraction of carbon associated with mud $\left(\mathrm{gC} \mathrm{g}^{-1}\right)$ are known, then the mass of carbon associated with sand may be determined via:

$500 \quad m_{\text {sand }}=\frac{P O C}{100} \cdot \operatorname{mud}\left(1+\frac{\text { sand }}{\text { mud }}\right)-w_{\text {mud }} \cdot$ mud

The mass fraction of carbon associated with sand ( $\mathrm{gC} \mathrm{g}^{-1}$ sand) was calculated for CEFAS data collected from the North Sea $(\mathrm{n}=148)$ and 5 grab samples collected from the Firth of Clyde in April and October 2017.

Figure A1 shows that there is no relationship between the mass fractions of carbon associated with sand and mud, suggesting that a single value for the mass fraction of carbon in sand may be applied to any sediment. Taking the mean carbon in sand 505 mass fraction for the available data yields $0.000301 \mathrm{gC} \mathrm{g}^{-1}$ sand.

These formulae were also used to calculate the mass fraction of nitrogen associated with sand $\left(\mathrm{gN} \mathrm{g}^{-1} \mathrm{sand}\right)$ for CEFAS ( $\mathrm{n}=$ $138)$ and Clyde Sea $(n=5)$ data. Similarly, no relationship between the mass fractions of nitrogen associated with sand and mud were observed (Figure A1). The mass fraction of nitrogen in sand may potentially vary as a function of the sand content. However, noise in the data prevents parametrisation of this relationship, and hence a mean nitrogen in sand mass fraction is used (0.000117 $\mathrm{gN} \mathrm{g}^{-1}$ sand). 

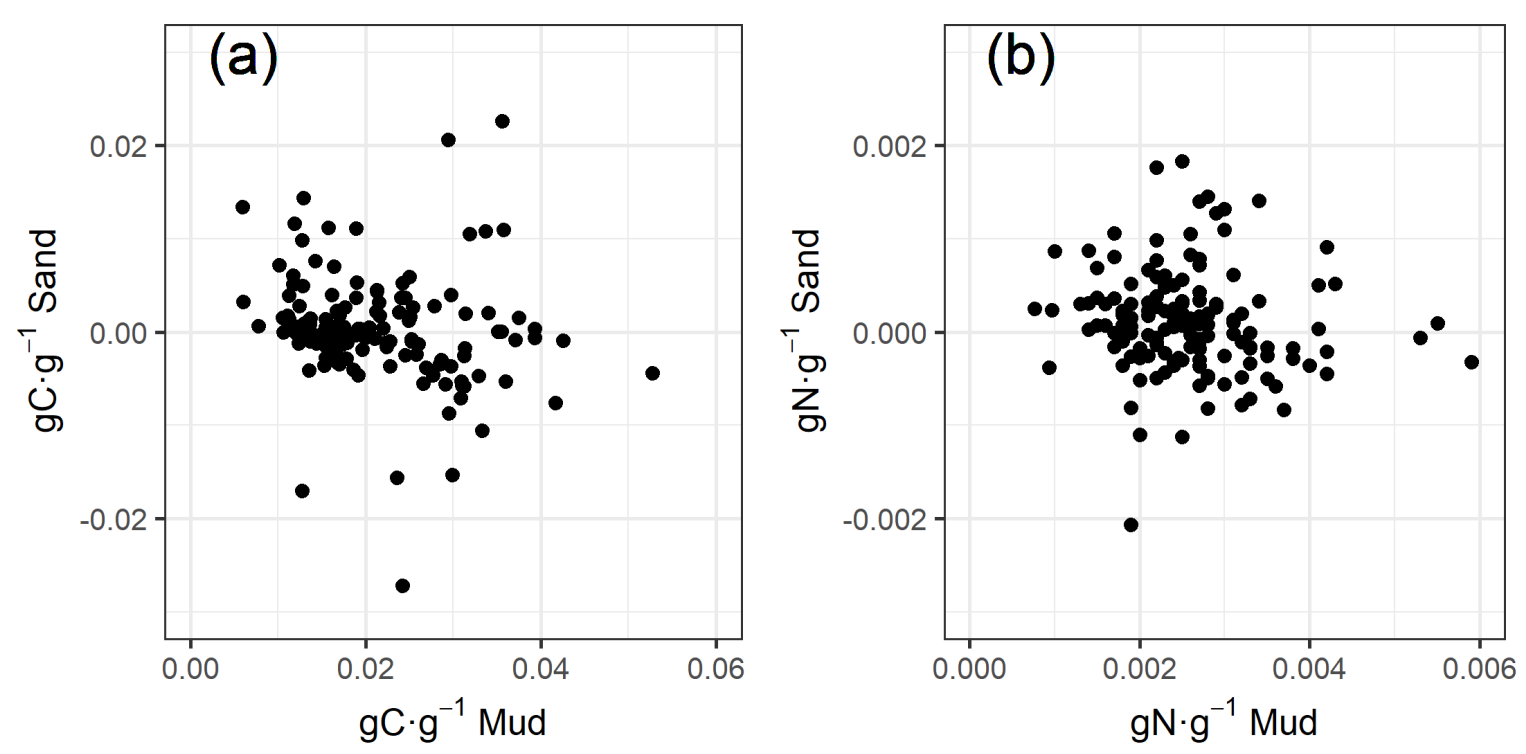

Figure A.1 Relationship between (a) the mass fraction of organic carbon in mud $\left(\mathrm{gC}^{-1}\right.$ mud) and in $\mathrm{sand}$ ( $\left.\mathrm{gC} \mathrm{g}^{-1} \mathrm{sand}\right)$ and (b) the mass fraction of organic nitrogen in mud $\left(\mathrm{gN} \mathrm{g}^{-1} \mathrm{mud}\right)$ and in sand $\left(\mathrm{gN} \mathrm{g}^{-1}\right.$ sand) for sediment collected from the North Sea by CEFAS and the Clyde Sea. 
https://doi.org/10.5194/essd-2021-23

Preprint. Discussion started: 17 May 2021

(c) Author(s) 2021. CC BY 4.0 License.

\section{References}

Blott, S. J. and Pye, K.: GRADISTAT: a grain size distribution and statistics package for the analysis of unconsolidated sediments, Earth Surf. Process. Landforms, 26(11), 1237-1248, doi:10.1002/esp.261, 2001.

Bolam, S. G., Garcia, C., Eggleton, J., Kenny, A. J., Buhl-Mortensen, L., Gonzalez-Mirelis, G., van Kooten, T., Dinesen, G.,

Hansen, J., Hiddink, J. G., Sciberras, M., Smith, C., Papadopoulou, N., Gumus, A., Van Hoey, G., Eigaard, O. R., Bastardie, F. and Rijnsdorp, A. D.: Differences in biological traits composition of benthic assemblages between unimpacted habitats, Mar. Environ. Res., 126, 1-13, doi:10.1016/j.marenvres.2017.01.004, 2017.

Burrows, M. T., Kamenos, N. A., Hughes, D. J., Stahl, H., Howe, J. A. and Tett, P.: Assessment of carbon budgets and potential blue carbon stores in Scotland's coastal and marine environment. Project Report. Scottish Natural Heritage Commissioned Report No. 761, , (7), 90 pp, 2014.

Cavalli, M., Tarolli, P., Marchi, L. and Dalla Fontana, G.: The effectiveness of airborne LiDAR data in the recognition of channel-bed morphology, Catena, 73(3), 249-260, doi:10.1016/j.catena.2007.11.001, 2008.

Chesher, J. A., Deegan, C. E., Ardus, D. A., Binns, P. E. and Fannin, N. G. T.: IGS marine drilling with m. v. Whitethorn in Scottish waters, 1970-71, Rep. Inst. Geol. Sci., No. 72/10, 25 pp., 1972.

530 Cowling, R. M., Egoh, B., Knight, A. T., O’Farrell, P. J., Reyers, B., Rouget, M., Roux, D. J., Welz, A. and Wilhelm-Rechman, A.: An operational model for mainstreaming ecosystem services for implementation, Proc. Natl. Acad. Sci. U. S. A., 105(28), 9483-9488, doi:10.1073/pnas.0706559105, 2008.

Craib, J. S.: A sampler for taking short undisturbed marine cores, ICES J. Mar. Sci., 30(1), 34-39, doi:10.1093/icesjms/30.1.34, 1965.

535 Davies, A. M., Hall, P., Howarth, M. J., Knight, P. J. and Player, R. J.: Tidal currents, energy flux and bottom boundary layer thickness in the Clyde Sea and North Channel of the Irish Sea, Ocean Dyn., 54(2), 108-125, doi:10.1007/s10236-003-0069-0, 2004.

Deegan, C. E., Kirby, R., Rae, I. and Floyd, R.: The superficial deposits of the Firth of Clyde and its sea lochs, Rep. Inst. Geol. Sci., No. 73/09, 42 pp., 1973.

540 Diesing, M., Kröger, S., Parker, R., Jenkins, C., Mason, C. and Weston, K.: Predicting the standing stock of organic carbon in surface sediments of the North-West European continental shelf, Biogeochemistry, 135(1-2), 183-200, doi:10.1007/s10533017-0310-4, 2017.

Ehrenhauss, S., Witte, U., Janssen, F. and Huettel, M.: Decomposition of diatoms and nutrient dynamics in permeable North Sea sediments, Cont. Shelf Res., 24(6), 721-737, doi:10.1016/j.csr.2004.01.002, 2004.

545 Eigaard, O. R., Bastardie, F., Breen, M., Dinesen, G. E., Hintzen, N. T., Laffargue, P., Mortensen, L. O., Nielsen, J. R., Nilsson, H. C., O’Neill, F. G., Polet, H., Reid, D. G., Sala, A., Sk?ld, M., Smith, C., S?rensen, T. K., Tully, O., Zengin, M. and Rijnsdorp, A. D.: Estimating seabed pressure from demersal trawls, seines, and dredges based on gear design and dimensions, ICES J. Mar. Sci., 73(suppl 1), i27-i43, doi:10.1093/icesjms/fsv099, 2016. 
https://doi.org/10.5194/essd-2021-23

Preprint. Discussion started: 17 May 2021

(c) Author(s) 2021. CC BY 4.0 License.

Eigaard, O. R., Bastardie, F., Hintzen, N. T., Buhl-Mortensen, L., Buhl-Mortensen, P., Catarino, R., Dinesen, G. E., Egekvist, J., Fock, H. O., Geitner, K., Gerritsen, H. D., González, M. M., Jonsson, P., Kavadas, S., Laffargue, P., Lundy, M., GonzalezMirelis, G., Nielsen, J. R., Papadopoulou, N., Posen, P. E., Pulcinella, J., Russo, T., Sala, A., Silva, C., Smith, C. J., Vanelslander, B. and Rijnsdorp, A. D.: The footprint of bottom trawling in European waters: Distribution, intensity, and seabed integrity, ICES J. Mar. Sci., 74(3), 847-865, doi:10.1093/icesjms/fsw194, 2017.

Fisher, P., Aumann, C., Chia, K., O’Halloran, N. and Chandra, S.: Adequacy of laser diffraction for soil particle size analysis, PLoS One, 12(5), 1-20, doi:10.1371/journal.pone.0176510, 2017.

Folk, R. L.: The distinction between grain size and mineral composition in sedimentary-rock nomenclature, J. Geol., 62(4), 344-359, 1954.

Gafeira, J., Green, S., Dove, D., Morando, A., Cooper, R., Long, D. and Gatliff, R. W.: Developing the necessary data layers for Marine Conservation Zone selection - Distribution of rock / hard substrate on the UK Continental Shelf - MB0103 Final Report., 2010.

Garrett, R. C., Nar, A. and Fisher, T. J.: ggvoronoi: Voronoi Diagrams and Heatmaps with "ggplot2". R package version 0.8.3, [online] Available from: https://cran.r-project.org/package=ggvoronoi, 2019.

Gregorutti, B., Michel, B. and Saint-Pierre, P.: Correlation and variable importance in random forests, Stat. Comput., 27(3), 659-678, doi:10.1007/s11222-016-9646-1, 2017.

565 Hastie, T., Tibshirani, R. and Friedman, J.: The Elements of Statistical Learning., 2009.

Heath, M. and Pace, M.: High resolution seabed sedimentology data for the Firth of Clyde, , doi:https://doi.org/10.15129/2003faa2-ee93-4c11-bb16-48485f5f136d, 2021.

Hiddink, J. G., Moranta, J., Balestrini, S., Sciberras, M., Cendrier, M., Bowyer, R., Kaiser, M. J., Sk??ld, M., Jonsson, P., Bastardie, F., Hinz, H. and Blanchard, J.: Bottom trawling affects fish condition through changes in the ratio of prey availability to density of competitors, J. Appl. Ecol., 53(5), 1500-1510, doi:10.1111/1365-2664.12697, 2016.

Hijmans, R. J.: geosphere: Spherical Trigonometry. R package version 1.5-10, [online] Available from: https://cran.rproject.org/package=geosphere, 2019.

Janssen, F., Huettel, M. and Witte, U.: Pore-water advection and solute fluxes in permeable marine sediments (II): Benthic respiration at three sandy sites with different permeabilities (German Bight, North Sea), Limnol. Oceanogr., 50(3), 779-792, doi:10.4319/lo.2005.50.3.0779, 2005.

Kamann, P. J., Ritzi, R. W., Dominic, D. F. and Conrad, C. M.: Porosity and permeability in sediment mixtures, Ground Water, 45(4), 429-438, doi:10.1111/j.1745-6584.2007.00313.x, 2007.

Klute, A. and Dirksen, C.: Hydraulic Conductivity and Diffusivity: Laboratory Methods, in Methods of soil analysis - part 1. Physical and mineralogical methods, edited by A. Klute, pp. 687-734, Soil Science Society of America (SSSA) / American 580 Society ofAgronomy, Inc. (ASA)), Madison, Wisconsin, Wisconsin., 1986.

Knudby, A., LeDrew, E. and Brenning, A.: Predictive mapping of reef fish species richness, diversity and biomass in Zanzibar using IKONOS imagery and machine-learning techniques, Remote Sens. Environ., 114(6), 1230-1241, 
https://doi.org/10.5194/essd-2021-23

Preprint. Discussion started: 17 May 2021

(c) Author(s) 2021. CC BY 4.0 License.

doi:10.1016/j.rse.2010.01.007, 2010.

Lepland, A., Rybalko, A. and Lepland, A.: Seabed Sediments of the Barents Sea. Scale 1:3 000 000., 2014.

Li, J., Heap, A. D., Potter, A. and Daniell, J. J.: Application of machine learning methods to spatial interpolation of environmental variables, Environ. Model. Softw., 26(12), 1647-1659, doi:10.1016/j.envsoft.2011.07.004, 2011.

Lohse, L., Malschaert, J. F. P., Slomp, C. P., Helder, W. and Vanraaphorst, W.: Nitrogen cycling in North Sea sediments Interaction of denitrification and nitrification in offshore and coastal areas, Mar. Ecol. Prog. Ser., 101(3), 283-296, doi:10.3354/meps101283, 1993.

Luisetti, T., Turner, R. K., Andrews, J. E., Jickells, T. D., Kröger, S., Diesing, M., Paltriguera, L., Johnson, M. T., Parker, E. R., Bakker, D. C. E. and Weston, K.: Quantifying and valuing carbon flows and stores in coastal and shelf ecosystems in the UK, Ecosyst. Serv., 35(January 2018), 67-76, doi:10.1016/j.ecoser.2018.10.013, 2019.

Maureaud, A., Hodapp, D., Daniël Van Denderen, P., Hillebrand, H., Gislason, H., Dencker, T. S., Beukhof, E. and Lindegren, M.: Biodiversity-ecosystem functioning relationships in fish communities: Biomass is related to evenness and the environment,

not to species richness, Proc. R. Soc. B Biol. Sci., 286(1906), doi:10.1098/rspb.2019.1189, 2019.

McIntyre, F., Fernandes, P. G. and Turrell, W. R.: Clyde Ecosystem Review., 2012.

Misiuk, B., Diesing, M., Aitken, A., Brown, C. J., Edinger, E. N. and Bell, T.: A spatially explicit comparison of quantitative and categorical modelling approaches for mapping seabed sediments using random forest, Geosciences, 9(6), 1-34, doi:10.3390/geosciences9060254, 2019.

600 Mitchell, P. J., Aldridge, J. and Diesing, M.: Legacy data: How decades of seabed sampling can produce robust predictions and versatile products, Geosciences, 9(4), doi:10.3390/geosciences9040182, 2019.

Moore, D. G. and Keller, G. H.: Marine sediments, geotechnical properties, in Applied Geology, edited by C. W. Finkl, pp. 343-350, Springer US, Boston, MA., 1984.

Neumann, A., Möbius, J., Hass, H. C., Puls, W. and Friedrich, J.: Empirical model to estimate permeability of surface sediments in the German Bight (North Sea), J. Sea Res., 127, 36-45, doi:10.1016/j.seares.2016.12.002, $2017 \mathrm{a}$.

Neumann, A., van Beusekom, J. E. E., Holtappels, M. and Emeis, K. C.: Nitrate consumption in sediments of the German Bight (North Sea), J. Sea Res., 127(June), 26-35, doi:10.1016/j.seares.2017.06.012, 2017b.

Palanques, A., Puig, P., Guillén, J., Demestre, M. and Martín, J.: Effects of bottom trawling on the Ebro continental shelf sedimentary system (NW Mediterranean), Cont. Shelf Res., 72, 83-98, doi:10.1016/j.csr.2013.10.008, 2014.

610 Pearson, T. H., Ansell, A. D. and Robb, L.: The Benthos of the Deeper Sediments of the Firth of Clyde, With Particular Reference to Organic Enrichment, Proc. R. Soc. Edinburgh, 90B, 329-350, 1986.

Portela, J., Cristobo, J., Ríos, P., Acosta, J., Parra, S., del Rio, J. L., Tel, E., Polonio, V., Muñoz, A., Patrocinio, T., Vilela, R., Barba, M. and Marín, P.: A First Approach to Assess the Impact of Bottom Trawling Over Vulnerable Marine Ecosystems on the High Seas of the Southwest Atlantic, in Biodiversity in Ecosystems - Linking Structure and Function, InTech., 2015.

615 Pusceddu, A., Bianchelli, S., Martín, J., Puig, P., Palanques, A., Masqué, P. and Danovaro, R.: Chronic and intensive bottom trawling impairs deep-sea biodiversity and ecosystem functioning., Proc. Natl. Acad. Sci. U. S. A., 111(24), 8861-6, 
https://doi.org/10.5194/essd-2021-23

Preprint. Discussion started: 17 May 2021

(c) Author(s) 2021. CC BY 4.0 License.

doi:10.1073/pnas.1405454111, 2014.

Qi, S., Wen, Z., Lu, C., Shu, L., Shao, J., Huang, Y., Zhang, S. and Huang, Y.: A new empirical model for estimating the hydraulic conductivity of low permeability media, Proc. Int. Assoc. Hydrol. Sci., 368(August 2014), 478-483, doi:10.5194/piahs-368-478-2015, 2015.

R Core Team: R: A Language and Environment for Statistical Computing, edited by R. D. C. Team, R Found. Stat. Comput., 1(3.6.0), doi:10.1007/978-3-540-74686-7, 2019.

Rijnsdorp, A. D., Bastardie, F., Bolam, S. G., Buhl-Mortensen, L., Eigaard, O. R., Hamon, K. G., Hiddink, J. G., Hintzen, N. T., Ivanović, A., Kenny, A., Laffargue, P., Nielsen, J. R., O’Neill, F. G., Piet, G. J., Polet, H., Sala, A., Smith, C., van Denderen,

P. D., van Kooten, T. and Zengin, M.: Towards a framework for the quantitative assessment of trawling impact on the seabed and benthic ecosystem, ICES J. Mar. Sci., 73(suppl 1), i127-i138, doi:10.1093/icesjms/fsv207, 2016.

Rijnsdorp, A. D., Bolam, S. G., Garcia, C., Hiddink, J. G., Hintzen, N. T., van Denderen, P. D. and van Kooten, T.: Estimating sensitivity of seabed habitats to disturbance by bottom trawling based on the longevity of benthic fauna, Ecol. Appl., 28(5), 1302-1312, doi:10.1002/eap.1731, 2018.

630 Ruardij, P. and Van Raaphorst, W.: Benthic nutrient regeneration in the ERSEM ecosystem model of the North Sea, Netherlands J. Sea Res., 33(3-4), 453-483, doi:10.1016/0077-7579(95)90057-8, 1995.

Sabatino, A. D., O’Hara Murray, R. B., Hills, A., Speirs, D. C. and Heath, M. R.: Modelling sea level surges in the Firth of Clyde, a fjordic embayment in south-west Scotland, Nat. Hazards, 1-23, doi:10.1007/s11069-016-2506-7, 2016.

Schiele, K. S., Darr, A., Zettler, M. L., Friedland, R., Tauber, F., von Weber, M. and Voss, J.: Biotope map of the German

Baltic Sea, Mar. Pollut. Bull., 96(1-2), 127-135, doi:10.1016/j.marpolbul.2015.05.038, 2015.

Serpetti, N., Heath, M., Armstrong, E. and Witte, U.: Blending single beam RoxAnn and multi-beam swathe QTC hydroacoustic discrimination techniques for the Stonehaven area, Scotland, UK, J. Sea Res., 65(4), 442-455, doi:10.1016/j.seares.2011.04.001, 2011.

Serpetti, N., Witte, U. F. M. and Heath, M. R.: Statistical modelling of variability in sediment-water nutrient and oxygen fluxes, Front. Earth Sci., 4(June), 1-17, doi:10.3389/feart.2016.00065, 2016.

Shepherd, R. G.: Correlations of Permeability and Grain Size, Ground Water, 27(5), 633-638, doi:10.1111/j.17456584.1989.tb00476.x, 1989.

Smeaton, C., Austin, W. E. N., Davies, A. L., Baltzer, A., Abell, R. E. and Howe, J. A.: Substantial stores of sedimentary carbon held in mid-latitude fjords, Biogeosciences, 13(20), 5771-5787, doi:10.5194/bg-13-5771-2016, 2016.

645 Smeaton, C., Austin, W. and Turrell, W. R.: Re-Evaluating Scotland's Sedimentary Carbon Stocks, Scottish Mar. Freshw. Sci., 11(2), doi:10.7489/12267-1, 2020.

Stephens, D. and Diesing, M.: Towards quantitative spatial models of seabed sediment composition, PLoS One, 10(11), 1-23, doi:10.1371/journal.pone.0142502, 2015.

Townsend, M., Thrush, S. F., Lohrer, A. M., Hewitt, J. E., Lundquist, C. J., Carbines, M. and Felsing, M.: Overcoming the challenges of data scarcity in mapping marine ecosystem service potential, Ecosyst. Serv., 8, 44-55, 
https://doi.org/10.5194/essd-2021-23

Preprint. Discussion started: 17 May 2021

(c) Author(s) 2021. CC BY 4.0 License.

doi:10.1016/j.ecoser.2014.02.002, 2014.

Turner, R.: deldir: Delaunay Triangulation and Dirichlet (Voronoi) Tessellation. R package version 0.1-16, [online] Available from: https://cran.r-project.org/package=deldir, 2019.

Valentine, P. C.: Sediment classification and the characterization, identification, and mapping of geologic substrates for the glaciated Gulf of Maine seabed and other terrains, providing a physical framework for ecological research and seabed management., 2019.

Van Der Wal, J., Falconi, L., Januchowski, S., Shoo, L. and Storlie, C.: SDMTools: Species Distribution Modelling Tools: Tools for processing data associated with species distribution modelling exercises. R package version 1.1-221.1, [online] Available from: https://cran.r-project.org/package=SDMTools, 2019.

660 Wei, C. L., Rowe, G. T., Briones, E. E., Boetius, A., Soltwedel, T., Caley, M. J., Soliman, Y., Huettmann, F., Qu, F., Yu, Z., Pitcher, C. R., Haedrich, R. L., Wicksten, M. K., Rex, M. A., Baguley, J. G., Sharma, J., Danovaro, R., MacDonald, I. R., Nunnally, C. C., Deming, J. W., Montagna, P., Lévesque, M., Weslawski, J. M., Wlodarska-Kowalczuk, M., Ingole, B. S., Bett, B. J., Billett, D. S. M., Yool, A., Bluhm, B. A., Iken, K. and Narayanaswamy, B. E.: Global patterns and predictions of seafloor biomass using random forests, PLoS One, 5(12), doi:10.1371/journal.pone.0015323, 2010.

665 Wentworth, C. K.: A Scale of Grade and Class Terms for Clastic Sediments, J. Geol., 30(5), 377-392, doi:10.1086/622910, 1922.

Wickham, H.: ggplot2: Elegant Graphics for Data Analysis, Springer-Verlag New York. [online] Available from: https://ggplot2.tidyverse.org, 2016.

Wiesner, M. G., Haake, B. and Wirth, H.: Organic facies of surface sediments in the North Sea, Org. Geochem., 15(4), 419670 432, doi:10.1016/0146-6380(90)90169-Z, 1990.

Wilson, A. M., Huettel, M. and Klein, S.: Grain size and depositional environment as predictors of permeability in coastal marine sands, Estuar. Coast. Shelf Sci., 80(1), 193-199, doi:10.1016/j.ecss.2008.06.011, 2008.

Wilson, R. and Heath, M.: bedshear: Calculations for bed shear stress and wave orbital velocity. R package version 0.1.0., 2019.

675 Wilson, R. J., Speirs, D. C., Sabatino, A. and Heath, M. R.: A synthetic map of the north-west European Shelf sedimentary environment for applications in marine science, Earth Syst. Sci. Data, 10(1), 109-130, doi:10.5194/essd-10-109-2018, 2018. Wright, M. N. and Ziegler, A.: ranger: A Fast Implementation of Random Forests for High Dimensional Data in C++ and R, J. Stat. Softw., 77(1), 1-17, doi:10.18637/jss.v077.i01, 2017. 